\title{
The 2021 eruption of the Cumbre Vieja Volcanic Ridge on La Palma, Canary Islands
}

Juan Carlos Carracedo ${ }^{1}$, Valentin R. Troll ${ }^{1,2}$, James M.D. Day ${ }^{3}$, Harri Geiger ${ }^{4}$, Meritxell Aulinas Junca ${ }^{5}$, Vicente Soler ${ }^{6}$, Frances M. Deegan ${ }^{2}$, Francisco J. Perez-Torrado ${ }^{1}$, Guillem Gisbert Pinto ${ }^{7}$, Esteban Gazel ${ }^{8}$, Alejandro Rodríguez-Gonzalez ${ }^{1}$, Helena Albert ${ }^{5}$

${ }^{1}$ Instituto de Estudios Ambientales y Recursos Naturales (i-UNAT), University of Las Palmas de Gran Canaria (ULPGC), 35017 Las Palmas de Gran Canaria, Spain ${ }^{2}$ Uppsala University, Dept. of Earth Sciences, Natural Resources \& Sustainable Development (NRHU), 75236 Uppsala, Sweden

${ }^{3}$ Scripps Institution of Oceanography, University of California San Diego, La Jolla, CA 92037, USA.

${ }^{4}$ University of Freiburg, Institute of Earth and Environmental Sciences, 79104 Freiburg im Breisgau, Germany

${ }^{5}$ University of Barcelona, Departament de Mineralogia, Petrologia i Geologia Aplicada, Marti Franques s/n, 08028, Barcelona, Spain

${ }^{6}$ IPNA-CSIC, La Laguna, Tenerife, Spain

${ }^{7}$ Instituto de Geociencias, CSIC-UCM, Severo Ochoa 7, 28040 Madrid, Spain

${ }^{8}$ Earth and Atmospheric Sciences, Cornell University, Ithaca, NY, USA

*Corresponding authors: Juan Carlos Carracedo 〈jcarracedo@proyinves.ulpgc.es>, Valentin R. Troll <valentin.troll@geo.uu.se>

STATEMENT: This article is a non-peer reviewed preprint, submitted to EarthArXiv. The article has been submitted to Geology Today 


\section{The 2021 eruption of the Cumbre Vieja Volcanic Ridge on La Palma, Canary Islands}

Juan Carlos Carracedo ${ }^{1}$, Valentin R. Troll ${ }^{1,2}$, James M.D. Day ${ }^{3}$, Harri Geiger ${ }^{4}$, Meritxell Aulinas Junca $^{5}$, Vicente Soler ${ }^{6}$, Frances M. Deegan ${ }^{2}$, Francisco J. Perez-Torrado ${ }^{1}$, Guillem Gisbert Pinto ${ }^{7}$, Esteban Gazel ${ }^{8}$, Alejandro Rodríguez-Gonzalez ${ }^{1}$, Helena Albert ${ }^{5}$

${ }^{1}$ Instituto de Estudios Ambientales y Recursos Naturales (i-UNAT), University of Las Palmas de Gran Canaria (ULPGC), 35017 Las Palmas de Gran Canaria, Spain ${ }^{2}$ Uppsala University, Dept. of Earth Sciences, Natural Resources \& Sustainable Development (NRHU), 75236 Uppsala, Sweden

${ }^{3}$ Scripps Institution of Oceanography, University of California San Diego, La Jolla, CA 92037, USA.

${ }^{4}$ University of Freiburg, Institute of Earth and Environmental Sciences, 79104 Freiburg im Breisgau, Germany

${ }^{5}$ University of Barcelona, Departament de Mineralogia, Petrologia i Geologia Aplicada, Marti Franques s/n, 08028, Barcelona, Spain

${ }^{6}$ IPNA-CSIC, La Laguna, Tenerife, Spain

${ }^{7}$ Instituto de Geociencias, CSIC-UCM, Severo Ochoa 7, 28040 Madrid, Spain

${ }^{8}$ Earth and Atmospheric Sciences, Cornell University, Ithaca, NY, USA

*Corresponding authors: Juan Carlos Carracedo <jcarracedo@proyinves.ulpgc.es〉, Valentin R. Troll <valentin.troll@geo.uu.se>

Almost exactly half a century after the eruption of the Teneguía Volcano on La Palma (26 October to 28 November 1971), a new eruption occurred on the island and lasted for 85 days from 19 September until 13 December 2021. This new eruption opened a volcanic vent complex on the western flank of the Cumbre Vieja rift zone, the N-S elongated polygenetic volcanic ridge that has developed on La Palma over the last c. $125 \mathrm{ka}$. The Cumbre Vieja ridge is the volcanically active region of the island and the most active one 
of the Canary Islands, hosting half of all the historically recorded eruptive events in the archipelago. The $2021 \mathrm{La}$ Palma eruption has seen no direct loss of human life, thanks to efficient early detection and sensible management of the volcanic crisis by the authorities, but more than 2800 buildings and almost 1000 hectares of plantations and farmland were destroyed. Satellite surveillance enabled accurate mapping of the progressive buildup of the extensive and complex basaltic lava field, which together with monitoring of gas emissions informed the timely evacuation of local populations from affected areas. Lava flows that reached the sea constructed an extensive system of lava platforms, similar to events during earlier historical eruptions, such as in 1712, 1949 and 1971. Long-term challenges in the aftermath of the eruption include protection of drainage systems from potential redistribution of tephra during high rainfall events, the use of the large surplus quantities of ash in reconstruction of buildings and in agriculture, and the crucial concerns of where and how rebuilding should and could occur in the aftermath of the eruption. Finally, there remains strong financial concerns over insurance for properties consumed or damaged by the eruption in light of future volcanic hazards from the Cumbre Vieja volcanic ridge.

\section{Geological Framework for the 2021 La Palma eruption}

Volcanic activity on La Palma has been exclusively centered on the southern part of the island in the last $125 \mathrm{ka}$, especially along the Cumbre Vieja volcanic ridge (Fig. 1). This most recent stage of La Palma's evolution has produced a $20 \mathrm{~km}$ long, $1950 \mathrm{~m}$ high N-Strending rift volcano, with a surface area of $220 \mathrm{~km}^{2}$. Along this ridge eruptive vents and fissures align with the volcano's crest to form a characteristic ocean island rift zone, locally known as a 'dorsal' (Fig. 1A). The majority of the volcanism on the Cumbre Vieja rift volcano comprises silica undersaturated basanite and alkali basalt, although volumetrically minor evolved differentiates such as phonolites are also found along the ridge. Most of the recent and historical volcanic emission centers concentrate along the Cumbre Vieja rift, which continues offshore for another $20 \mathrm{~km}$ beyond the southern tip of the island, forming a chain of young and recently active submarine volcanoes.

Previous eruptions of the Cumbre Vieja include 7 out of the 14 historical (witnessed and documented) eruptions recorded in the Canary Islands, making the Cumbre Vieja rift zone statistically the most probable site of future volcanic activity in the archipelago (Table 1). The sketch in Fig. 1B shows the internal structure of the Cumbre Vieja rift zone as has been envisaged by Carracedo and coauthors in 2001 on the basis of eroded rift systems on the older island of Tenerife. Below the aligned cinder cones and their associated deposits on the surface, the core of the rift zone is made up by a tightly packed dyke swarm that 
represents the feeder conduits to the surface vents and cinder cones. Intrusion of one such dyke, or possibly a series of dykes, in early September 2021 led to the opening of an eruptive vent at a few minutes after 2 pm local time on September 19, 2021 in the Cabeza de Vaca area on the western flank of the Cumbre Vieja ridge (Fig. 2). The 2021 eruptive activity occurred almost exactly 50 years after the 1971 Teneguía eruption that took place at the southern tip of the Cumbre Vieja ridge and near the western lava flows and vents of the preceding 1949 eruption (see Fig. 1A). The most recent 2021 eruption was preceded since 2017 by relatively deep $(25-35 \mathrm{~km})$ but low magnitude seismic activity, with the eruption itself taking place after a week of intense seismic unrest and ground deformation in mid September 2021, leaving only a very limited time window for coordinated disaster mitigation and civil protection measures. The area affected by the 2021 eruption consists of a gently sloping plain on the lower flanks of the Cumbre Vieja, at an altitude of 1000 masl, in an area that is relatively densely populated. This topography resulted from previous voluminous pre-historic eruptions, such as the Birigoyo Volcano (dated at $6 \pm 2$ ka) that smoothed the local terrain, contrasting with the steeper slopes of the southern part of the Cumbre Vieja ridge (Fig. 2). In addition, the northern part of the Cumbre Vieja preserves a shallow-marine abrasion platform that is absent in the southern part of the ridge. This platform is connected to the Last Glacial Maximum (LGM), which occurred $20 \mathrm{ky}$ ago. The LGM corresponds to the stage when the continental ice sheets reached their maximum total mass during the last ice age, and the global sea level was 120-135 m lower than at present, allowing the shallow fringe of this coastal abrasion platform to form. This was discussed in detail by Carracedo and coworkers in 2001, realizing that in the marginal portions of the Cumbre Vieja, the LGM abrasion platform now provides a shallow submarine substrate on which recent lavas can form characteristic lava deltas or platforms, such as the 1712, 1949 and 1971 eruptions, and now also the most recent 2021 eruption.

\section{Timeline of the 2021 Eruption}

The 2021 La Palma eruption classifies as a basaltic fissure type eruption, dominated by strombolian activity and with episodic phreatomagmatic pulses. The eruption, opened several vents as it progressed, ultimately building up a sizable cinder cone and an extensive lava flow field. This newly formed volcanic structure is about $200 \mathrm{~m}$ high from its base, with a total altitude of 1131 m.a.s.l. and six major craters on its top define the main 560 m long NW-SE eruptive alignment (Fig. 3).

Throughout the eruption, the intensity of the explosive activity was reflected through the eruptive column that was typically around 3,500 meters above sea level, although peaks of higher column height occurred and with a maximum height of 8,500 
meters was recorded on December 13. The plume height together with a volume of emitted pyroclastic material of about 45 Million $\mathrm{m}^{3}$ (total pyroclastic deposits and lavas together exceeded 200 Million $\mathrm{m}^{3}$ ), and the characteristics of the eruption, define the event as a (VEI) 3 on the Volcanic Explosivity Index.

During the eruption, fine lapilli and ash were an almost constant eruption product and thickly mantled the western flank of the Cumbre Vieja ridge, but during westernly wind periods, ash fall also affected the eastern side of the island reaching the airport and the island's capital Santa Cruz (Fig. 4). Lapilli, finely fragmented lava particles ( $>2$ to $<64$ $\mathrm{mm}$ ) of basanite composition were the typical emitted material. Because basanite magmas are generally of low viscosity, volatiles effectively degas, commonly leading to lava fountains (Strombolian-type) and very fluid lava flow (Hawaiian-type) eruptions. Basanitic Strombolian eruptions are mildly explosive, producing rhythmic pyroclastic bursts of fluid lava that usually solidifies in flight, creating fragments of hardened lava of a few $\mathrm{mm}$ to a few $\mathrm{cm}$ in size, but occasionally also reaching meters in size (known then as volcanic bombs). Bombs and lapilli usually follow balistic trajectories falling in proximal areas (generally less than one $\mathrm{km}$ ) from the vent (Fig. 4). Finer ash particles (less than $2 \mathrm{~mm}$ in size) originate in more explosive phases of Strombolian eruptions and are frequently dispersed for greater distances from the eruptive center. The $2021 \mathrm{La}$ Palma eruptive column dispersed falls of fine-fragmented ash hundreds of kilometers away from the volcano. In addition to fine ash, volatiles such as $\mathrm{SO}_{2}$ may also travel for thousands of kilometers and fine ash and volatile components from La Palma have not only been detected on the neighboring islands of El Hierro and Tenerife, but as far afield as the Caribbean and Central Europe (Fig. 4F).

Another important aspect of the 2021 eruption was that the lava flows had relatively high eruption temperatures (max. $1140{ }^{\circ} \mathrm{C}$ ) and were consequently very fluid at times (Fig. 5A), with velocities of some channelised lava flows exceeding $30 \mathrm{~km} /$ hour. However, upon cooling, the viscosity of lavas increased (Fig. 5B-D), producing slower-moving blocky lava flow facies beyond the major channels and, as a result, breakout tongues and overflow frequently stopped even on relatively steep slopes, a characteristic of non-Newtonian fluids. The result of these viscosity changes were a range of lava flow forms, from minor relatively thin, and often channelized pahoehoe-type flows, to major a'a' blocky lava flows that moved at less than $1 \mathrm{~meter} / \mathrm{min}$, and locally produced accretionary balls at the leading edges of the flow fronts. La Palma 2021 a'a' lava flows show a rough, scoriaceous and highly fractured surface, unlike the pahoehoe lavas (which do not usually reach more than one meter thickness), a'a' lavas lobes reach several meters in thickness. During the course of the eruption, the changing topography and lava flow dynamics led to a complex range 
of temporally distinct anastomosing lava tongues and channels, with younger flows often covering older flows and generating a maximum accumulation thickness of 70 meters in the center of the lava field and an average lava thicknesses of 12 meters.

Lava flows travelled distances beyond $6.5 \mathrm{~km}$ onshore and up to $1.1 \mathrm{~km}$ under the sea. Lavas reached the sea for the first time on September 28 in the area of Playa de los Guirres, forming a lava delta. The successive arrivals of the lava flows to the sea, some of them drained through lava tubes, resulted in the formation of a second lava delta. The main one, located to the south, represents the amalgamation of three temporary deltas initially separated from each other but progressively expanded to make the main delta. The total area lava claimed from the sea during the eruption is ca. $50 \mathrm{ha}$, and thus the island of La Palma grew by this surface area during the 2021 eruption events.

Notably, the tephrite to basanite lavas that erupted are compositionally similar to historical eruptions in La Palma (see Fig. 6), fitting the overall chemical pattern of the Cumbre Vieja volcanic system. The 2021 La Palma lavas sampled until early December are porphyritic, variably vesiculated, and with a phenocryst content of subhedral and compositionally zoned clinopyroxene as the main mineral phase and lesser amounts of olivine crystals in early erupted lavas. The phenocrysts are immersed in a very fine-grained groundmass. Interestingly, brown amphibole phenocrysts are present in the earliest lavas emitted by the volcano, with clear reaction textures indicating disequilibrium with the carrying melt. As the eruption proceeded into late October and November, no more amphibole was present and olivine increased in abundance instead.

Another notable feature of the 2021 eruption is the presence of xeno-pumice fragments, a type of frothy xenolith that occurred during approximately the first half of the La Palma eruption (Fig. 7). Two main types have been identified, a white type and a grey one. The white type resembles those previously identified in El Hierro by Troll and coworkers in 2011/2012, whereas the grey xeno-pumice bears similarities with frothy phonolitic xenolith in some earlier eruption on La Palma as has been recorded by e.g. Carracedo and Troll in 2016. Notably, xeno-pumice was commonly found amongst the tephra in the first half of the eruption, but stopped being present amongst the tephra deposits in the later weeks of November, so that during the 2 nd half of the eruption an almost complete absence of xeno-pumice was noted. Xeno-pumice fragments are not uncommon on La Palma and in other Canary Island eruptions and are known from the eruption of. Timanfaya on Lanzarote in 1730-36, San Juan in 1949 and Teneguía in 1971 on La Palma, and from Montañón Negro on Gran Canaria ca. 3000 years BP, as has been discussed by Carracedo and colleagues in 2015. This list now also includes the 2021 event and 
preliminary major element analysis for sodium, potassium and silica content shows the white La Palma 2021 xeno-pumice to be of a rhyolitic composition (see white star in Fig. 6), likely representing frothed up fragments of sedimentary materials from the ocean crust similar to the white xeno-pumice material from El Hierro that were analysed by Troll and colleagues and by Zaczek and coworkers in 2015. The grey xeno-pumice type that occured in the $2021 \mathrm{La}$ Palma eruption is akin to the composition of typical phonolites from the Cumbre Vieja volcano. The grey phonolitic xeno-pumice type was also observed in some historical eruptions such as in the 1585 Jedey eruption on La Palma, and thus represents dominantly older phonolite intrusive materials. Notably, unlike at El Hierro in 2011, where initial misunderstanding of xeno-pumice as precursors to potentially explosive eruption of high silica magma prompted authorities to repeatedly evacuate the village of La Restinga, the La Palma 2021 xeno-pumice samples were correctly interpreted as relatively harmless xenolith that are more of a scientific curiosity than a signal for an increase of the eruption's hazard potential.

\section{Early detection, monitoring and management of the 2021 eruption}

The effective hazard management is clearly a remarkable triumph resulting from the 2021 La Palma eruption. The implemented measurements and policies, avoided any direct human fatalities from volcanic activity by securing the eruption site and limiting damage as much as possible due to evacuations and rapid emergency repair efforts inside the exclusion zone. This was possible through early detection using seismic arrays, deformation analysis, satellite-based geodetics, and gas monitoring carried out by several organisations (e.g. IGN, CSIC and INVOLCAN) that were coordinated by the Volcanic Emergency committee PEVOLCA. This management effort led to the evacuation of almost 8000 people, a significant part of the population of the Aridane Valley, the main settlement area on the western side of La Palma (see Fig. 2). The analysis of seismic activity and ground deformation was of critical importance, not only in the early detection of the unrest that led to the eruption and in predicting it's most likely location, but also as principal elements for monitoring the entire eruptive event and the continued supply of magma to the vent site from depth. Seismically grouped hypocentres defined two zones beneath the surface: a deeply located hypocentre zone between 30 and $40 \mathrm{~km}$, and a shallower hypocentre region between 10 and $15 \mathrm{~km}$ (Fig. 8). Crucially, in the days just prior to the eruption, swarms of earthquakes allowed to trace the journey of the rising magma towards the surface (blue dots in Fig. 8A), indicating an increasing probability of volcanism 
surfacing at the NW end of the Cumbre Vieja ridge. The diagram in Fig. $8 \mathrm{~B}$ differentiates both pre-eruptive and subsequent eruptive activity from a seismic perspective, and in the latter one, part of the progressive increase of activity and the waning stage towards the end of the eruption on December 13. Moreover, a series of consecutive INSAR images of the Cumbre Vieja area taken by the Copernicus satellite detected millimeter scale differences in the terrain and this ground deformation indicated the zone of maximum deformation in the area where the eruptive centre would eventually open (Fig.9).

Volcanic gases, mainly $\mathrm{CO}_{2}, \mathrm{SO}_{2}$ and $\mathrm{H}_{2} \mathrm{O}$, that were dissolved in the ascending magma exolved when the magma approached shallower levels during ascent, increasing the gas pressure within the conduit system, and ultimately, acting as a propellant for magma to feed the surface eruption (Fig.10). When reaching the surface, these volatiles commonly generate an eruption column driven by expanding gas bubbles, as seen exemplified by the sustained eruption column during the La Palma events, causing the magma to fragment and to be thrown out of the vent as tephra (bombs, lapilli, or ash). These particles travel initially with ballistic trajectories and the eruptive column is sustained by the upward thrust of the gas jet at high pressure and temperature, constituting the kinetic sector of the column. The ingestion of cold atmospheric air, known as entrainment by the eruptive column, lowers its temperature and pressure, creating a convective regime until it reaches a height where the rising hot air equals the density of the cold air outside the column, ultimately establishing a level of neutral buoyancy (Fig. 10). The finer particles are then transported horizontally by the prevailing winds until they finally rain out if overcome by gravity, which can lead to dispersion distances of 100s to even 1000s of kilometers (see Fig. 4A). Incandescent pyroclasts of $>64 \mathrm{~mm}$ size ejected from active volcanoes known as 'bombs' are commonly considered to fall ballistically, so the extent of the area affected by this volcanic hazard can be easily mapped, and was limited to one km-radius from the vents. However, a new form of bomb was recognized by our team to form by initial ejection from the volcano followed by gravitational transport down the volcano flank during the 2021 La Palma eruption (Fig. 11). These bombs were observed to spall hot material during transport on the soft, lapilli and ash covered substrate or on impact with pre-exisiting hardened lava flows, leading to fragmentation into incandescent pieces that posed a significant fire and impact hazard, and they have therefore been termed 'spallation bombs' by our team.

Detailed satellite imagery depicting the progression and growth of the lava field was possible through the European Union Copernicus Programme, where dedicated satellites (the Copernicus Sentinel family) provided a constant stream of information that was validated by data collected on the ground. The map in Fig. 12A shows the different lava flows branching downslope from the vent towards the ocean at progressive stages defined 
by Copernicus satellite data. Fig. 12 B shows the thickness of lava flows on January 1, 2022 , with a total volume of $188,000,000 \mathrm{~m}^{3}$ covering an area of a little over $12 \mathrm{~km}^{2}$, equivalent to a time-average discharge rate of $27 \mathrm{~m}^{3} / \mathrm{second}$. Lava flows arrived close (80 m) to the coastal cliff on October 17 and 21, November 24, and December 5. Flows reached the sea on several occasions during the eruption, forming a series of lava deltas (Figs. 12 \& 13), the most extensive one just north of the previous 1949 lava delta and a smaller one resting on the 1949 flows. The interaction of these incandescent lava flows with the ocean water led to plumes of steam, local explosive interactions and distinct volcanic forms from those that occurred on land, including submarine pillow structures and local hyaloclastite layers.

\section{The eruption - its dangers and its effects}

The area affected by the lavas of the 2021 eruption was the extensive sloping plain of Los Llanos de Aridane ("llanos" meaning plains in Spanish), and unfortunately one of the most populated and most prosperous agricultural and tourist areas of La Palma. This circumstance, together with the unexpected magnitude of the 2021 volcano, made this eruptive episode the most disastrous in the recorded history of the island.

A notable aspect of the fissure eruptions in the Canary Islands is the formation of several, often aligned, eruptive vents. During the $2021 \mathrm{La}$ Palma eruption, as in the 1712 El Charco eruption, eruptive vents aligned at about $45^{\circ}$ against the slope. This arrangement causes the venting to occur at different altitudes, operating through an arrangement that produces a "chimney" effect. The arrangement favours the vent system to mainly degas through the upper (higher altitude) vents while the lava flows usually erupt from the lower altitude vent openings. Very hot $\left(1140^{\circ} \mathrm{C}\right)$, dense and fluid lava flows advanced along a front of more than $3 \mathrm{~km}$, sweeping away over 2800 buildings, leaving over 350 hectares of productive farmland (banana plantations, avocado plantations, vineyards) covered by lava, and buried over $70 \mathrm{~km}$ of vital roads, including the main North - South connection (LP-2) of the Western side of the Island. This severely disrupted the crucial transport system in that part of La Palma, forcing traffic and supply transportation to take the much longer route around the Eastern side of the Cumbre Vieja with considerable addition of costs and a severe reduction of transport efficiency in the entire southern part of the island. The destructive advance of a'a' lava, despite obstacles, is because lava flows constitute, for the most part, a Newtonian fluid, i.e. a fluid that offers resistance to movement, and so their advance requires that a lava flow continue to be fed from an eruptive centre. If this 
contribution is steady state, the lava flows act like "huge bulldozers" at their front that sweep away everything in their path, demolishing houses and roads with great ease (Figs. $5 \& 14)$. If the supply of lava at the vent ceases, however, lava fronts and tongues stop and cool irrespective of topography. The change in the environment before and after the passage of the lava flows is overwhelming and gives a clear idea of the power of this process.

Volcanic gases also caused severe disruption, forcing confinement of the population and the cessation of public activities (e.g. school attendance) in certain areas. This "unfavourable air condition" was particularly severe during the final stages of the eruption, when $\mathrm{SO}_{2}$ emission rates were exceptionally high (over 50,000 tonnes), likely from degassing of primitive magma stuck inside the plumbing system emitting gas from decompressive exsolution. Alone or in combination with high concentrations of dangerous gases, ambient concentrations of fine particulate volcanic matter forced repeated confinement of communities exposed to volcanic emissions beyond the area of direct impact of the 2021 eruption. Fine particulate matter PM10 describes all airborne particles with diameters less than $10 \mu \mathrm{m}$, a grain size not detectable during breathing and which will cause fine material to be lodged deep in the respiratory system. Episodes of high PM10 concentration of for example $225 \mu \mathrm{g} / \mathrm{m}^{3}$ at the Los Llanos station on November 2nd dramatically exceeded the threshold set at $50 \mu \mathrm{g} / \mathrm{m}^{3}$, causing "extremely unfavourable air quality". This forced population confinement in the Valle de Aridane area and although people tried to maintain normal activities as much as possible under these conditions, questions remain about long-term health risks from prolonged or chronic exposure to even moderately elevated PM10 values, based on the now well-recognized morbidity and mortality effects (asthma, chronic bronchitis and emphysema) from epidemiological studies (cf. EEA, 2012).

\section{Crucial lessons learned from the 2021 Eruption}

A positive lesson from this eruption is that effective crisis management protocols are now in place in the Canary Islands, as reflected in the absence of direct volcano casualties, apart from one fatality that resulted from indirect causes. Indeed, crisis management policies and protocols worked highly effectively on La Palma in 2021 and marks a clear improvement in comparison to previous volcano crisis handling (cf. discussion in e.g. Perez-Torrado and coworkers 2012 and Carracedo and colleagues 2015). Contrasting with the poorly 
monitored 1971 Teneguía eruption on the southern tip of the onshore Cumbre Vieja ridge, the 2021 event is by far the best monitored volcanic crisis in the Canary Islands. The advanced technical surveillance available now provides valuable scientific information and a sound basis for civil protection measures that will serve as a model for future volcanic crises on the Cumbre Vieja ridge and likely for other ocean island volcanoes worldwide. Specifically, surveillance of the lava flows with UAV (Unmanned Aircraft Vehicle) equipped with optical and thermal cameras was crucial to follow the lava lobes advances and allowed timely evacuations and emergency preparations to be carried out. The 2021 crisis has given us the knowledge that adverse effects from future eruptions in the Canaries can be mitigated if properly monitored, forecasted and managed, despite the high population density of the Canary Islands and the relatively long inter-eruptive periods between major volcanic events.

After the end of the eruption on December 13 and the 10-days safeguard extension by the managing authorities for its official announcement, ahead lies a challenging, laborious and costly period of reconstruction of the areas affected by the eruption. This includes (re-)building of houses and utility buildings to replace the over 1300 homes and ca. 1500 utility buildings destroyed by the eruption (Fig. 15). Challenges will include the assessment of which remnants can be reconstructed and which may need to be entirely demolished before being reconstructed. Building on the new lava will have to adapt to the new topographic conditions of up to 70-m-thick lava flows and assessment will be required if lava tunnels exist below certain spots on the lava field, probably making rebuilding directly on the lava a costly exercise. Removal of lava, in turn, will require blasting and intense labour to break the lava rock and pave the ground for new constructions. Crucially, the reconstruction of the lost road connections will be vital and will thus see investment of considerable effort and time, especially as it offers the opportunity for a re-planning of the road network to accommodate the needs of the growing population in the western part of the island.

A commodity not easily replaced, however, is the significant portion of the fertile and agriculturally highly productive land of the Aridane Valley (chiefly banana and avocado plantations, but also wine and pineapples etc.). These lands have disappeared, covered by lava flows and/or thick lapilli beds. The future use of this new territory as farmland will require costly and laborious investment in the process of "sorribado", a local term meaning to prepare the land for farming by adding new soil on top of the fresh lavas, a process recently described by Troll and coworkers in 2017 and which has already been successfully applied to the 1949 and 1971 lava flows and especially their lava deltas (see Fig. 2). 
Moreover, reconstruction will need to take much care to at least in part preserve the natural beauty of the newly formed volcanic landscapes in a way to ultimately favor preservation of crucial volcanological features, while simultaneously allowing for nature based tourism, the most significant economic resource of this part of the island. It is important to note that article 132.2 of the Spanish Constitution stipulates that any new land reclaimed from the sea in case of a volcanic eruption becomes governmental property. The new lava deltas that formed in 2021 are now governmental lands by definition, which raises the possibility of saving this new lava delta sequence as a valuable educational and touristic resource. This could take the form of a nature park (e.g. a Volcano Park) or even a demarcated nature reserve, perhaps with a visitor center and marked footpaths to allow visitors to enjoy the beauty of the volcanic features while ensuring minimal impact on these landforms from large numbers of visitors.

One problem remains, however, regardless of the enormous improvements in the early detection and use of scientific monitoring instrumentation. This is to create a system that guarantees provisions that can alleviate the costs associated with the losses that occur to local populations in such natural disasters that are of foreseeable recurrence. Models from other active volcanic areas very similar to the Canary Islands (e.g., the Hawaiian Islands) may need to be investigated and perhaps adopted. On the Big Island of Hawaii volcanic hazards are more frequent than in the Canary Islands and therefore the population is more aware and volcanic phenomena are taken into account in urban planning, specific housing design, and in road construction techniques, and, importantly, there are compensation options via insurance premiums that are especially designed for volcanic eruptions. In the case of Hawaii, most standard insurances cover damage to houses and property directly caused by a volcanic eruption, including damages caused outdoors by lava flows or falling tephra (volcanic bombs, pyroclasts) and fires that may result from e.g. hot spallation bombs or lava incinerations. Damage insurance can even cover appliances such as TV sets, furniture, clothing, and possible acts of looting. The costs for living elsewhere until the volcanic risks have subsided can also be included, as can the maintenance and repair costs that may arise until a dwelling is habitable again.

A significant aid to premium assessment is the best possible knowledge of the expected volcanic hazards and associated risks, i.e. the foreseeable frequency of eruptions in a given area, and the anticipated estimation of the type and distribution of destructive elements, particularly lava flows (Fig. 15 A). Luckily, all recorded (historical) eruptions in the Canary islands are of the same fissure fed cinder cone and lava flow type, making assessment of future volcanic hazards from eruptions in the archipelago at least qualitatively achievable within this framework of previous knowledge. In particular, the 
maximum damage caused by a possible eruption of the kind expected in the Canary Islands (fissure fed basaltic cinder cones and lava flows) can be analyzed with methods similar to those used for large floods, where the decisive factor is the existing topography. As in the estimation of flood areas, there are programs based on geographic information systems (GIS) and digital terrain models (DTM), optimizable with the use of satellites and lidar points, which can cross-reference data from the terrain, roads, houses and other properties, with the projection of the lava flow for given volumes, i.e: successive stages during eruption progress (see Fig. 16 B). Employment of this method on islands such as El Hierro, Tenerife, Lanzarote and La Palma would yield a detailed analysis to draw up a potential hazard map for each island that would enable estimation of the expected damage for the various areas of the volcanically active ridges and valleys alike.

In summary, the 2021 event is a typical Strombolian fissure fed cinder cone eruption with lava emissions, characteristic of the recent activity of the Cumbre Vieja Volcano Ridge and also of historical volcanism in the Canary islands in general. While the 2021 eruptive event on La Palma was of unusually large volume and duration, it is of great value to realize that the fundamental volcanological pattern is identical to those observed in the historical record. It is now up to us to reconcile the eruptive style of Canary fissure type basaltic eruptions with the possibility that their location might be in very populated and prosperous areas (agriculture, tourism, infrastructures). The lessons learned at La Palma give the potential for inhabitants of the Canary Islands to prepare for, and mitigate against, future human and economic losses caused by volcanic activity on La Palma and the other islands in the Canary archipelago in the decades to come.

\section{Acknowledgements}

We are grateful to the PEVOLCA committee for permission to work within the exclusion zone during the eruption on La Palma and are indebted to the Guardia Civil, the Bomberos (Fire Brigade) and the Military Emergency Unit (UME) for on the ground help and support during our field effort. We moreover like to thank the people of La Palma for their generosity in times of crisis and for access to many places where important geological observations were made. We also thank Wim Coen for providing some of the lava field images and Malin Andersson for help with compiling the figures. 


\section{Further Reading}

Carracedo, J.C., Rodríguez Badiola, E., Gouillou, H., De La Nuez, J. \& Pérez Torrado, F.J. 2001. Geology and volcanology of La Palma and El Hierro, Western Canaries. Estudios Geológicos, v.57, pp.175-273.

Carracedo, J.C., Badiola, E.R., Guillou, H., Paterne, M., Scaillet, S., Torrado, F.J.P., Paris, R., Fra-Paleo, U., \& Hansen, A. 2007. Eruptive and structural history of Teide Volcano and rift zones of Tenerife. Canary Islands. Geological Society of America Bulletin, v.119, pp.1027-1051.

Carracedo, J.C., Pérez-Torrado, F., Rodríguez-González, A., Fernández-Turiel, J.L., Troll, V.R. \& Wiesmaier, S. 2012. The 2011 submarine volcanic eruption in El Hierro (Canary Islands). News Feature, Geology Today, v.28, pp.53-58.

Carracedo, J.C. \& Troll, V.R. (2016). The Geology of the Canary Islands. Elsevier, Amsterdam.

Carracedo, J.C.,Troll, V.R., Zaczek, K., Rodríguez-González, A., Soler, V. \& Deegan, F.M. 2015. The 2011-2012 submarine eruption off El Hierro, Canary Islands: New lessons in oceanic island growth and volcanic crisis management. Earth-Science Reviews, v.150, pp.168-200.

Carracedo, J.C. \& Troll, V.R. 2021. North-East Atlantic Islands: The Macaronesian archipelagos (Azores, Madeira, Canary Islands and Cape Verde). In: Encyclopedia of Geology, pp.674-699. Academic Press, London.

Day, J. M. D., Pearson, D. G., Macpherson, C. G., Lowry, D. \& Carracedo, J.C. 2010. Evidence for distinct proportions of subducted oceanic crust and lithosphere in HIMU-type mantle beneath El Hierro and La Palma, Canary Islands. Geochimica et Cosmochimica Acta, v.74, pp.6565-6589.

European Environment Agency. 2012. Particulate matter from natural sources and related reporting under the EU Air Quality Directive in 2008 and 2009. 43 pp.

Green, B.D. \& Rose, W.I. 1999. Volcanic Risk Map for Santa María, Guatemala: What can Risk Maps Contribute to Volcanic Hazard Communications? (http://www.geo.mtu.edu/volcanoes/santamaria/volcrisk/)

IGN (Instituto Geográfico Nacional). (https://www.ign.es/web/ign/portal/vlc-areavolcanologia) 
Pérez-Torrado, F.J., Carracedo, J.C., Rodríguez-González, A., Soler, V., Troll, V.R. \& Wiesmaier, S. 2012. The submarine eruption of La Restinga (El Hierro, Canary Islands): October 2011 - March 2012. Estudios Geológicos, v.68, pp. 5-27.

PEVOLCA (Plan Especial de Protección Civil y Atención de Emergencias por riesgo volcánico en la Comunidad Autónoma de Canarias). (https://info.igme.es/eventos/Erupcion-volcanica-la-palma/pevolca)

Rodriguez-Gonzalez, A., Fernandez-Turiel, J.L., Perez-Torrado, F.J., Hansen, A., Aulinas, M., Carracedo, J.C., Gimeno, D., Guillou, H., Paris, R. \& Paterne, M. 2009. The Holocene volcanic history of Gran Canaria island: implications for volcanic hazards. Journal of Quaternary Science, v.24(7), pp.697-709.

Torres-González, P.A., Luengo-Oroz, N., Lamolda, H., D’Alessandro, W., Albert, H., Iribarren, I., Moure-García, D. \& Soler, V. 2020. Unrest signals after 46 years of quiescence at Cumbre Vieja, La Palma, Canary Islands. Journal of Volcanology and Geothermal Research, v.392, p.106757.

Troll, V.R., Klügel, A., Longpré, M.-A., Burchardt, S., Deegan, F.M., Carracedo, J.C., Wiesmaier, S., Kueppers, U., Dahren, B., Blythe, L.S., Hansteen, T., Freda, C., Budd, D.A., Jolis, E.M., Jonsson, E., Meade, F., Harris, C., Berg, S., Mancini, L., Polacci, M. \& Pedroza, K. 2012. Floating stones off El Hierro, Canary Islands: xenoliths of pre-island sedimentary origin in the early products of the October 2011 eruption. Solid Earth, v.3, pp.97-110.

Troll, V.R., Deegan, F.M., Burchard, S., Zaczek, K., Carracedo, J.C., Meade, F.C., Soler, V., Gachao, M., Ferreira, J. \& Barker, A.K. 2015. Nannofossils: The smoking gun for the Ganarian hotspot. Geology Today v.31(4), pp. 137-145.

Troll, V.R., Carracedo, J.C., Jägerup, B., Streng, M., Barker, A.K, Deegan, F.M., Pérez-Torrado, F.J., Rodriguez-Gonzalez, A. \&Geiger, H. 2017. Volcanic particles in agriculture and gardening. Geology Today v.33(4), pp.148-154.

Zaczek, K., Troll, V.R., Cachao, M., Ferreira, J., Deegan, F.M., Carracedo, J.C., Soler V., Meade, F.C. \& Burchardt, S. 2015. Nannofossils in 2011 El Hierro eruptive products reinstate plume model for Canary Islands. Scientific Reports v.5, p.7945. 


\section{Figure Captions}

Fig. 1. A. The Cumbre Vieja rift zone forms the southern half of the island of La Palma (see inset) and is the volcanically most active region in the Canary Islands. It produced more than half of all the archipelago's historical eruptions (i.e. over approx. the last 500 years; See Table 1). B. The Cumbre Vieja volcanic ridge was constructed in the last 125,000 years and is composed of a densely packed, N-S aligned cluster of cinder cones and their corresponding lava flows that are predominant on the ridge flanks. The internal structure below the cinder cones is composed of a dense dyke swarm, many of the dykes representing the feeder conduits of past eruptions.

Fig. 2. The area affected by the 2021 eruption, the Los Llanos de Aridane zone ("Llanos" means "plains" in Spanish), centralizes an essential part of the population and economic resources (banana plantations, tourism) of La Palma. The area consists of a gently inclined flatland on the north-western flank of the Cumbre Vieja ridge (at an altitude of 50-1000 m.a.s.l.). This comparatively smooth topography, the result of voluminous prehistoric eruptions such as the Birigoyo Volcano (dated at $6 \pm 2 \mathrm{ka}$ ), contrast the steeper slopes of the southwestern part of the Cumbre Vieja ridge, where erosion is predominant. In addition, an extensive shallow marine abrasion platform formed during the last glacial maximum (ca. $20 \mathrm{ka}$ ago), which allows the Holocene lava flows to form coastal platforms and lava deltas to the NW of the Cumbre Vieja ridge, as exemplified in the 2021 volcanic event. Image Credit: European Union, Copernicus Sentinel 2 satellite image from January 3, 2021.

Fig. 3. A. View of the new volcano cone from the West (from El Paso), showing the open western crater and extensive sulfur deposits that formed after the termination of the eruption from degassing of sulphur rich vapours. B. \& C. Views of the new volcano edifice from the East, showing an ash covered crater landscape. A total of six major craters developed during the 3 months eruption, which is typical for the multi-vent eruption style of many of the historical volcanic events on La Palma and in the Canary Islands in general.

Fig. 4. A The 2021 La Palma eruption classifies as a monogenetic basaltic Stromboliantype fissure eruption, opening several vents as the eruption progressed to ultimately build up a sizable cinder cone. B-E. Lapilli deposits thickly mantled roads and houses in the Valle de Aridane area. The almost constant lapilli airfall strongly affected the western flank of the Cumbre Vieja ridge, but also reached the airport and the island's capital Santa Cruz on the eastern side during periods where winds were flowing in from the West. F. Aerosols of fine particles and of volcanic gasses, such as $\mathrm{SO}_{2}$, and fine ash particles reached Central America and also Western and Central Europe (Image. Credit: CAMS Forecast 
of total column of sulphur dioxide for Thursday 23 Sep, 2021, Copernicus Atmosphere Monitoring Service/ECMWF).

Fig. 5. Lava flows were one of the most destructive features during the $2021 \mathrm{La}$ Palma eruption. A. Rivers of lava were emitted from the central cone system and flowed downhill at enormous speed during several episodes of the eruption as the lava temperature commonly exceeded $1100^{\circ} \mathrm{C}$ near the vent (max. $1140^{\circ} \mathrm{C}$ ). These channelised (thermally insulated) lava flows allowed rapid and efficient lava transport all the way to the sea (see below). B. \& C. Frontal lava tongues and overbank facies, in turn, cooled rapidly and became blocky lava flows that advanced in caterpillar mode, slowly progressing towards building and destroying all man-made structures in their way, like this house in the Las Manchas area. D. If the supply of lava at the vent ceases, lava fronts and tongues stop and freeze irrespective of topography, like here in La Laguna village showing the edge of a lava tongue that entered the town. This shift to a'a' style emplacement, acting similar to a huge bulldozer at their front, can sweep away everything in their path and demolish man made structures such as houses with great ease, and contrasts the mode of thinner lava emplacement at higher temperatures that was frequently flowing around houses (E), thus creating islands of relict infrastructure (kipukas) within the main lava field.

Fig. 6. A. Thin section image of a lava sample erupted on September 22 in crossedpolarized light, showing amphibole with a reaction rim as well as pyroxene set in a microlitic groundmass. B. Thin section image of lava sample erupted on November 25 also in cross-polarized light, showing complex zonation and a cloudy core in larger pyroxene and some small clots of olivine and pyroxene. The larger grey areas are vesicles in both images. Note the larger grain size of the main phenocrystals later in the eruption, signaling that different magmatic source regions have likely been tapped during different episodes of the eruption on La Palma. C. Major element analysis for sodium, potassium and silica content of historical eruptions on La Palma (grey area with specific examples as coloured dots). The data define a mafic array in the basanite section of the diagram. White xeno-pumice samples from El Hierro, in turn, show a high-silica rhyolite composition (white stars), while the outer black coat to the xeno-pumice is of basanite composition (see also Fig. 7). D. The tephrite to basanite lavas that erupted in 2021 are compositionally similar to historical eruptions in La Palma, thus they broadly fit the overall chemical pattern of the Cumbre Vieja volcanic system. The 2021 La Palma lavas show, however, a compositional difference between early and late erupted lava samples that reflects a progressively more mafic character of the eruption products with ongoing eruptive duration and indicates different source regions to be involved. The white 2021 La Palma xeno-pumice (see text and Fig. 7) is similar in composition to the 2011 El Hierro white xeno-pumice, implying a dominantly sedimentary ocean crust origin for this inclusion type. The grey xeno-pumice found in the 2021 La Palma tephras, in turn, represents frothed up intrusive phonolites, similar to what has been seen previously in 
older La Palma eruptions. For instance, the 1585 Jedey eruption was fed through a vent that intersected an older phonolite spine complex, picking up considerable amounts of older phonolite intrusive materials that are now found as frothy phonolite xeno-pumice in the 1585 lavas.

Fig.7. Comparison of "coconut-type" rhyolitic xeno-pumice from the 2011-2012 submarine eruption of El Hierro (A.) and white xeno-pumice of the 2021 subaerial eruption of La Palma (B.). These samples consist of white, frothy, high-silica material mantled by dark, basanite, host magma. Sample in (A.) is ca. $5 \mathrm{~cm}$ across. Sample in (B.) has a pen for scale. The El Hierro 2011 xeno-pumice specimen were determined to represent frothed up fragments of sedimentary materials from the ocean crust due to their highsilica rhyolite composition, their high oxygen isotope values, and their considerable content of nannofossils and abundant quartz. The 2021 La Palma xeno-pumice samples overlap in major element composition with the El Hierro examples and we can hypothesize that they are likely of oceanic sedimentary origin as well.

Fig. 8. Seismic unrest data from La Palma (Source: Instituto Geográfico Nacional; IGN). A. Beneath the surface of La Palma, the 2021 eruption hypocentres defined a deep (between 30 and $40 \mathrm{~km}$ ) and a shallower zone (between 10 and $15 \mathrm{~km}$ ). In the days just prior to the eruption, swarms of seismic activity allowed to trace the journey of the rising magma towards the surface (blue dots), which indicated that volcanism would be surfacing at the NW end of the Cumbre Vieja ridge. B. The timeline diagram differentiates both pre-eruptive and subsequent eruptive activity from a seismic perspective, and shows the progressive increase of seismic activity before and during the eruption and the waning of seismic intensity towards its end in the middle of December 2021.

Fig. 9. Intense ground deformation near the eruption site at La Palma, localized by Copernicus Sentinel 1 between September 14 and 20, 2021. Deformation affected the NW flank of the Cumbre Vieja ridge all the way to the coastline. Ground deformation indicated a zone of maximum uplift in the area where the eventual eruptive vents opened.

Fig. 10. A. Photograph of the south end of La Palma from the International Space Station taken on October 4, 2021. The oblique camera angle provides a three-dimensional view of the volcanic plume rising over low-level clouds. The north to south wind direction moves the plume away from the airport, located further down the lower right of the image. B. The lower volcanic plume as seen during the eruption from the ground (viewed from the SW). Wind blowing towards the NE led to cancellation of air traffic, leaving the ferry as the only feasible connection to and from the island. C. Particles travel with ballistic trajectories and the eruptive column is initially sustained by the upward thrust of the gas jet at high pressure and temperature, constituting the kinetic sector of the column (more 
explanations in the text). Larger and denser particles then fall out, whereas finer and lighter particles can be transported further from the vent by wind and air currents.

Fig. 11. A large volcanic bomb that was observed being ejected from the volcano and to roll down the volcano's slopes on tephra beds down the lower volcano flanks near the evacuated settlement of Las Manchas during the 2021 La Palma eruption. The bomb shows an incandescent inner core with partial vitrophyric coating. Hammer head is $19 \mathrm{~cm}$ in length. This one and similar bombs were observed to spall hot material during transport on the soft, lapilli and ash-covered substrate or on impact with pre-existing hardened lava flows, thus representing a considerable fire and impact risk in the vicinity of the active volcanic cone.

Fig. 12. A. Successive stages of growth of the lava field during the 2021 La Palma eruption as determined by Copernicus Satellite information (<https://emergency.copernicus.eu/mapping/list-of-components/EMSR546>).

Temporally distinct lava lobes are separated by colours and patterns. Also indicated are the eruptive vents (marked by stars) and the successive lava deltas that formed in the coastal area west of the volcano (D1-D4). The pre-eruption coastline is marked by the blue stippled line. B. Extent of lava flows on Jan 1, 2022, totaling a volume of 194.000 .000 $\mathrm{m}^{3}$, and covering an area of $12.35 \mathrm{~km}^{2}$, equivalent to a time-average discharge rate of $27 \mathrm{~m}^{3} / \mathrm{s}$. Data and credit: JMC Belart from the elevation differential Lidar 2016 (IGN, Spain) and Pléiades Jan. 1, 2022).

Fig. 13. Flows reached the sea on several occasions during the eruption forming a series of lava deltas (see Figs 2. \& 12.), including an extensive one that in part overlaps with the older 1949 lava delta and a later smaller one that occurs to the north of the main delta. A. \& B. Impressions of the northern smaller lava delta showing the cliffs and the cascaded lavas as well as the delta that extended the coast. C. Photo of 2021 lava that overlies the 1949 lava delta (which hosts extensive banana plantations by now).

Fig. 14. A. Lava field in late October (28th) viewed from the older La Laguna cinder cone. B. Lava field in January 2022 showing lava flows that migrated around plantation walls near La Laguna village. C. The extensive lava field in January 2022 viewed from it's NW edge (near Los Llanos) looking East. D. Lava incursion into a banana plantation near Los Llanos.

Fig. 15. Cleaning the thick lapilli deposits and reconstruction are the primary tasks after the eruption. A.-D. Houses need to be cleaned and safety checked for structural damage and gas pockets and traps before populations can return to the properties that were not swallowed up by lava or collapsed under the weight of the ash. E.\& F. Transport of lapilli to temporary pile-up sites allow storage of large amounts of ash before being hopefully 
redeployed as concrete supplements, aggregates in road construction, and soil supplements in agriculture. Images are from San Nicolás and the Las Manchas region.

Fig. 16. A. A probabilistic map from the initial stage of the 2021 eruption in La Palma (produced in late September) that shows the results of a simulation of the possible paths the lava would travel from the specific emission zone of the 2021 volcano. Increasing eruptive lava thickness is shown from green to red, with red areas being the most probable lava paths that would also produce the thickest lava flow deposits. In the model, all the coloured zones are attainable by lava flows (image from A. Felpeto, IGN). B. Geographic Information System (GIS) maps compiled for the Santa Maria Volcano (Guatemala) and its surroundings that combine volcanic hazard zonations with four layers of economic and population data (population, infrastructure, land use, and standard of living) following from work by Green and Rose in 1999). This single map presents the risks from volcanic activity and could be a basis for assessing insurance premiums in volcanically active areas such as the Canary Islands.

Table 1. Some critical features of the Canary Islands historical eruptions (last 500 years). Seven eruptive events out of 15 have occurred in La Palma, including this 2021 latest eruption. 


\section{FIGURES}
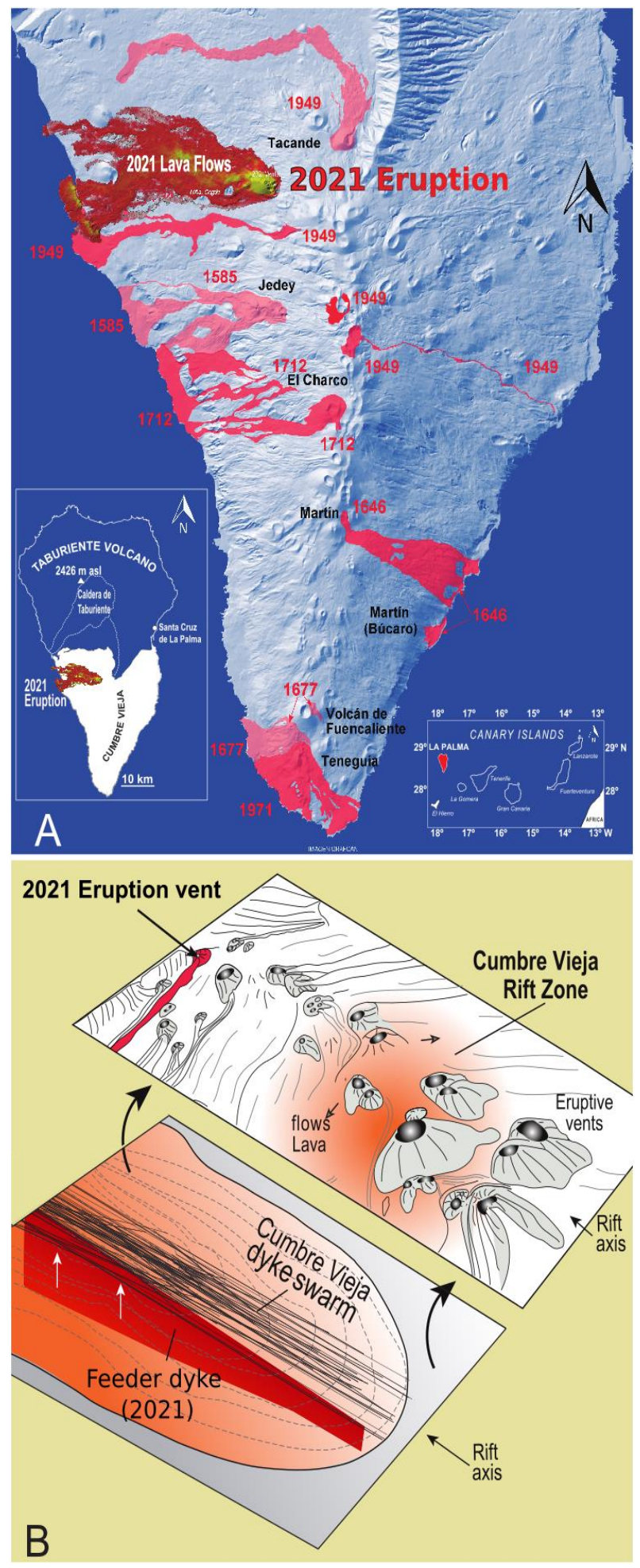

Fig. 1 


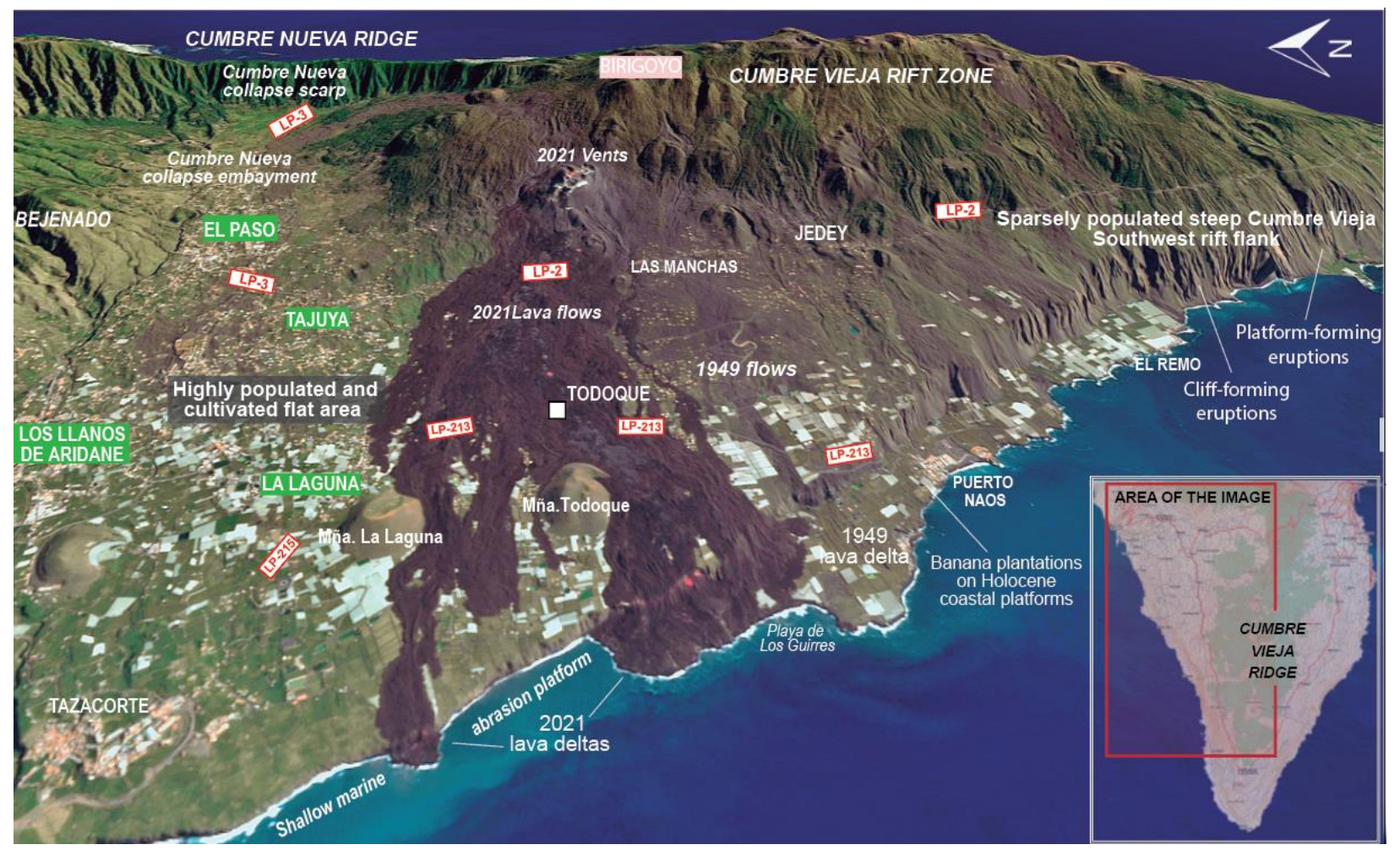

Fig. 2 


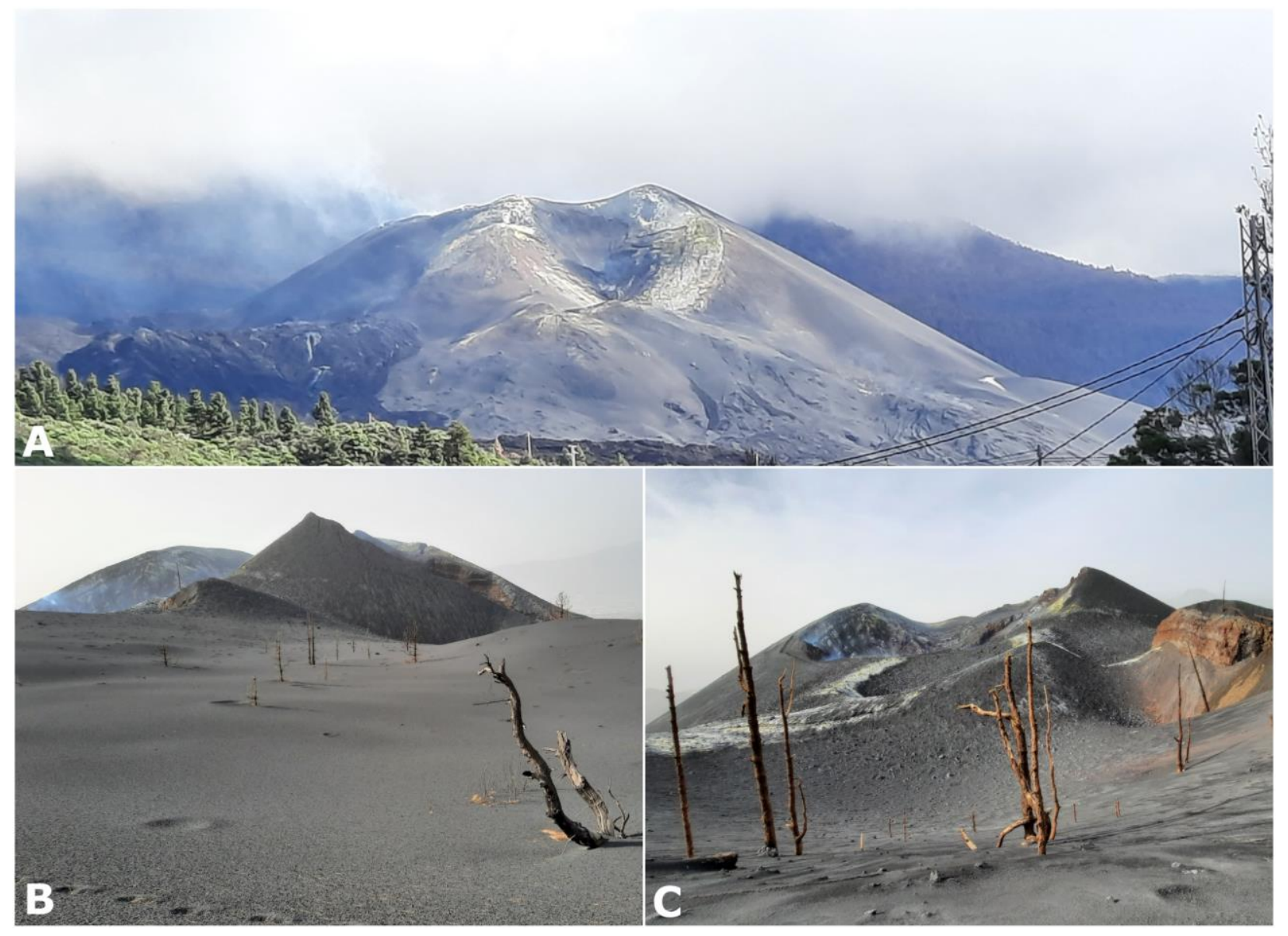

Fig 3. 


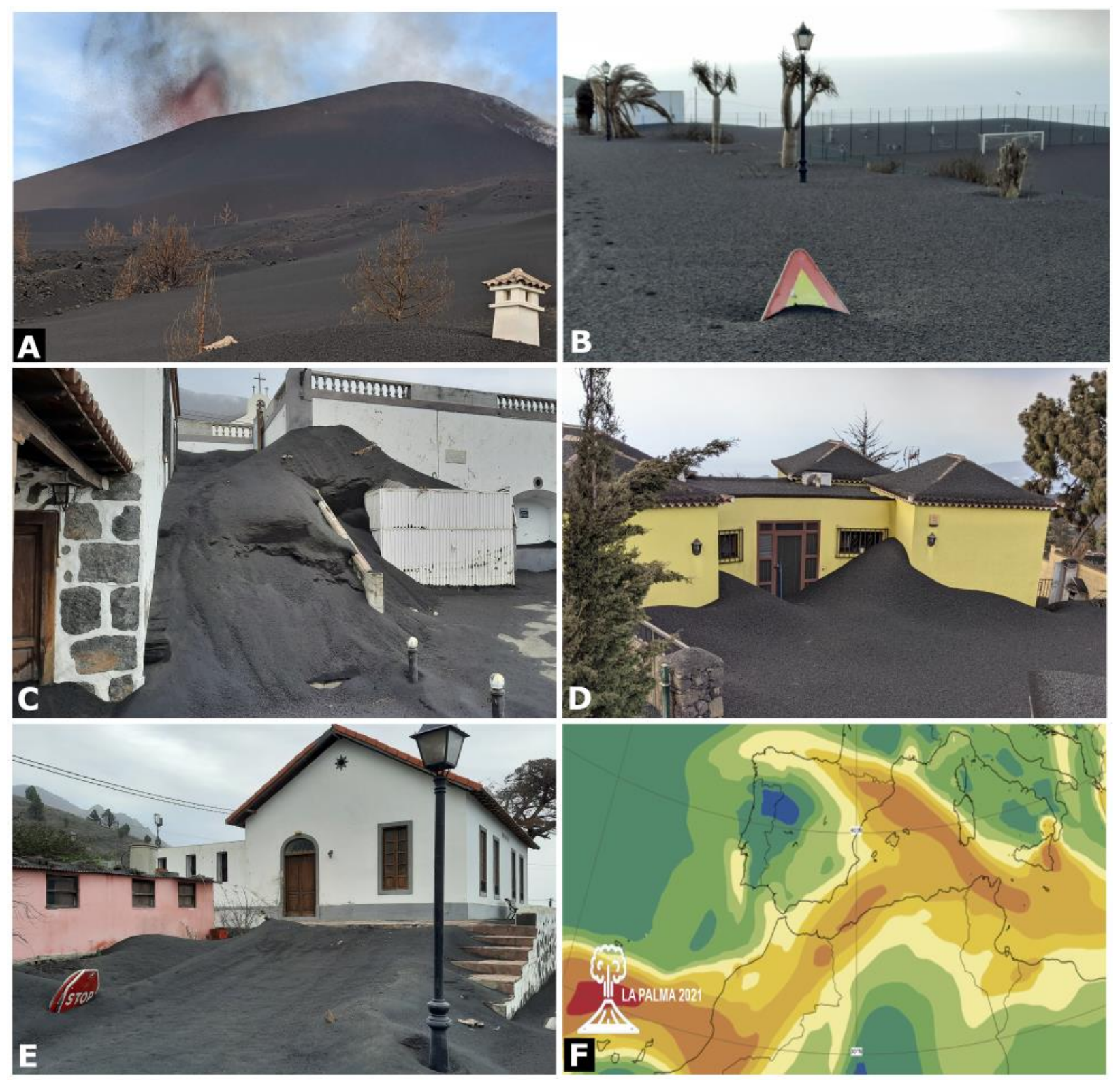

Fig 4. 

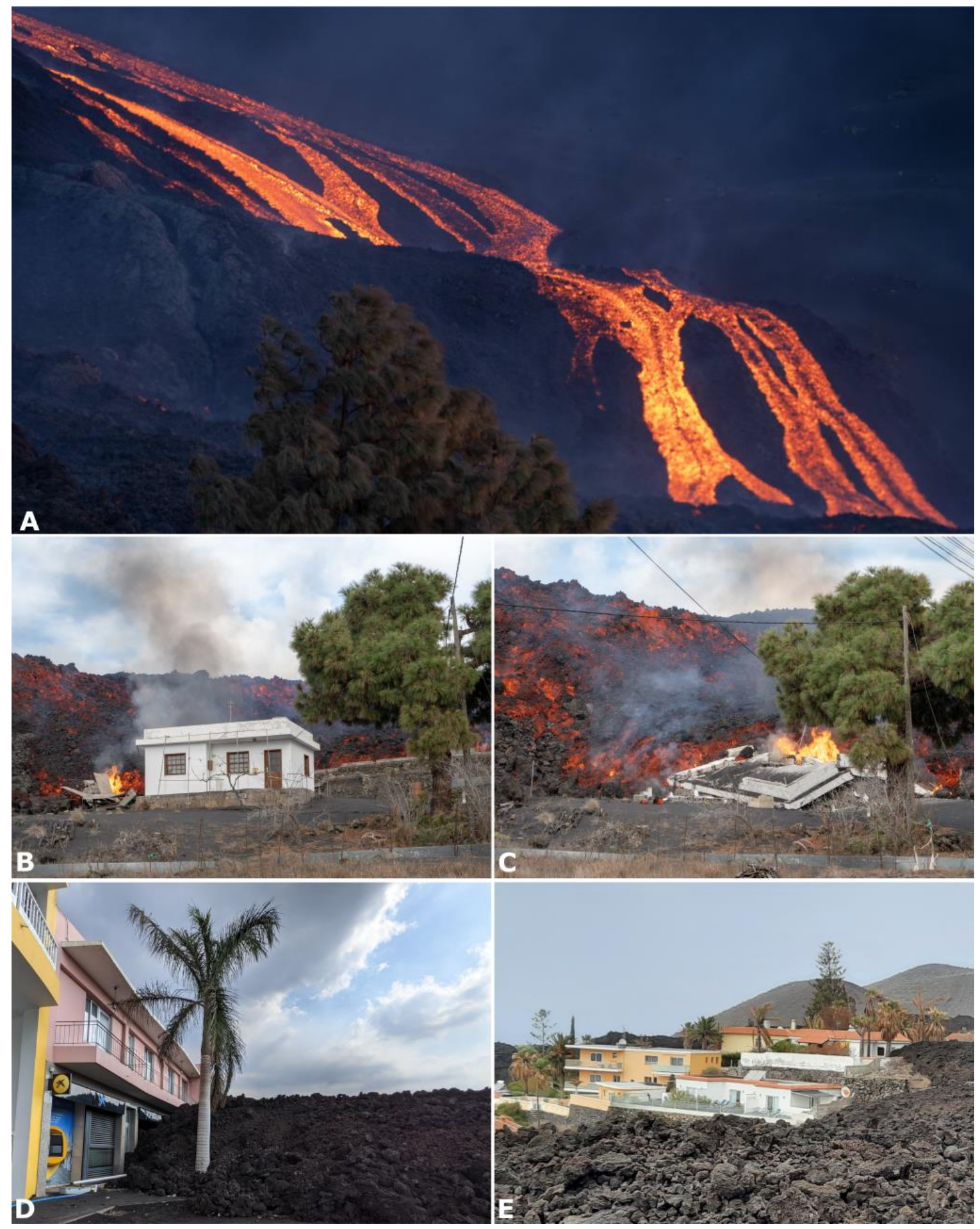

Fig. 5 

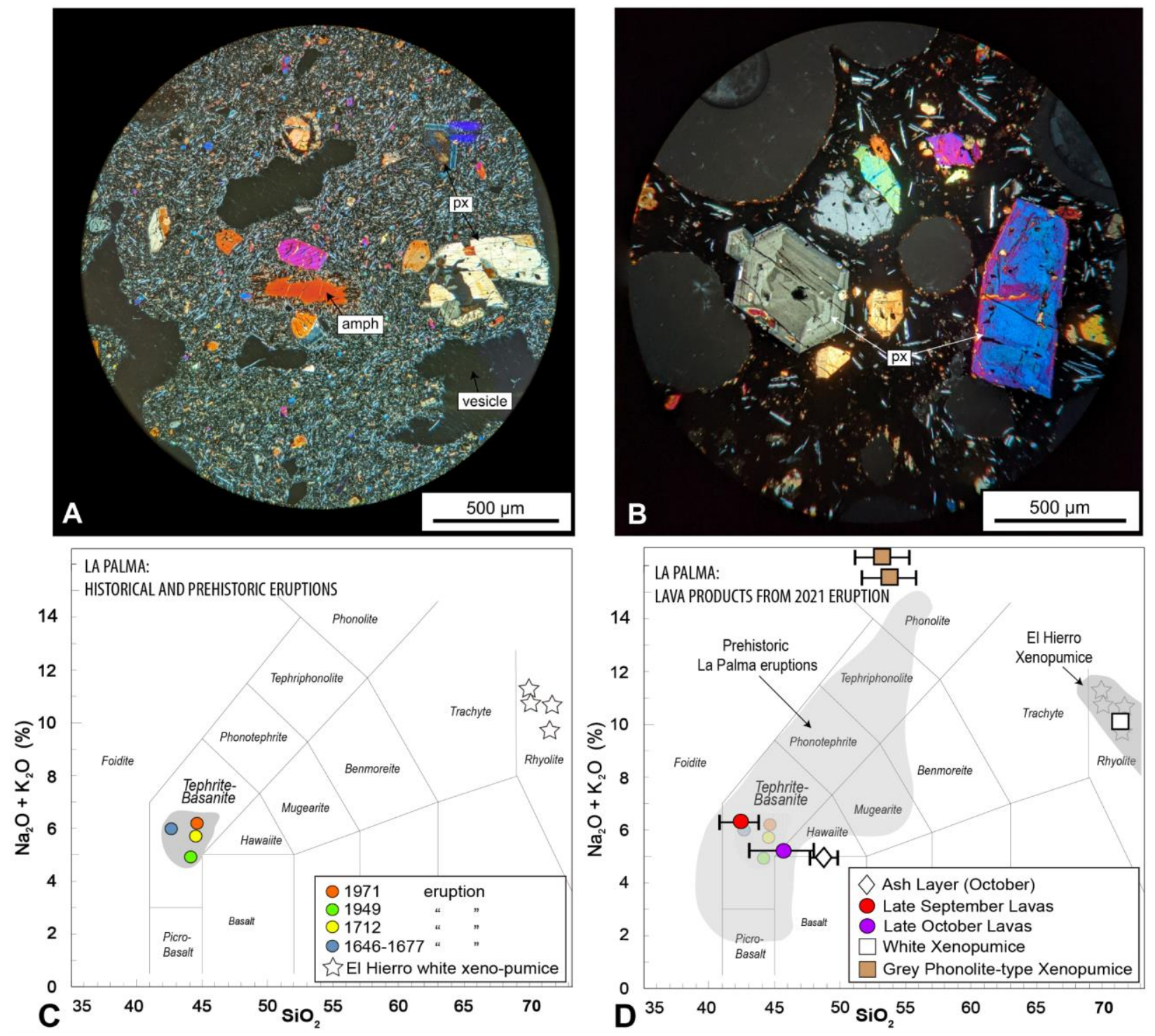

Fig. 6 

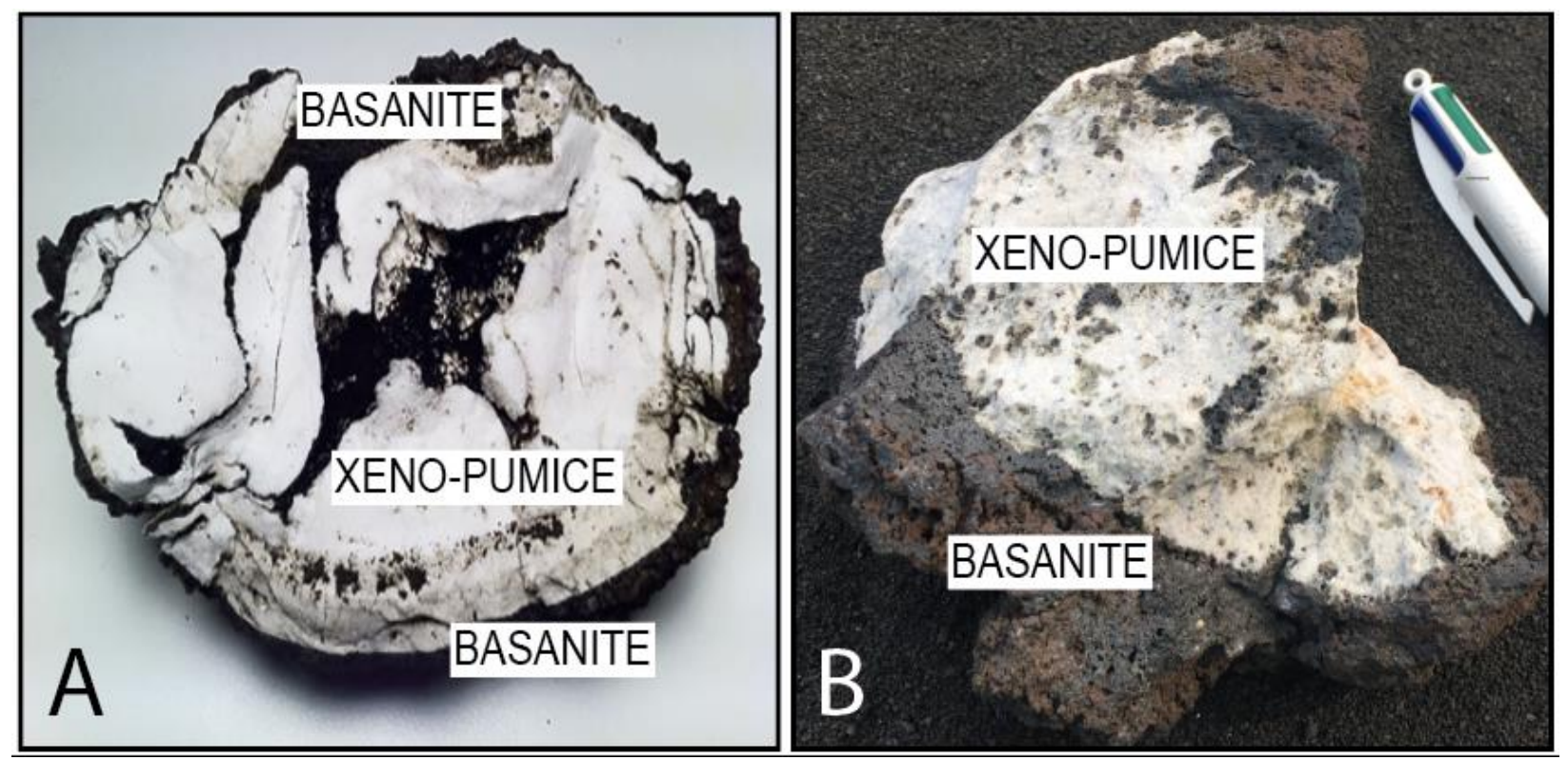

Fig 7. 

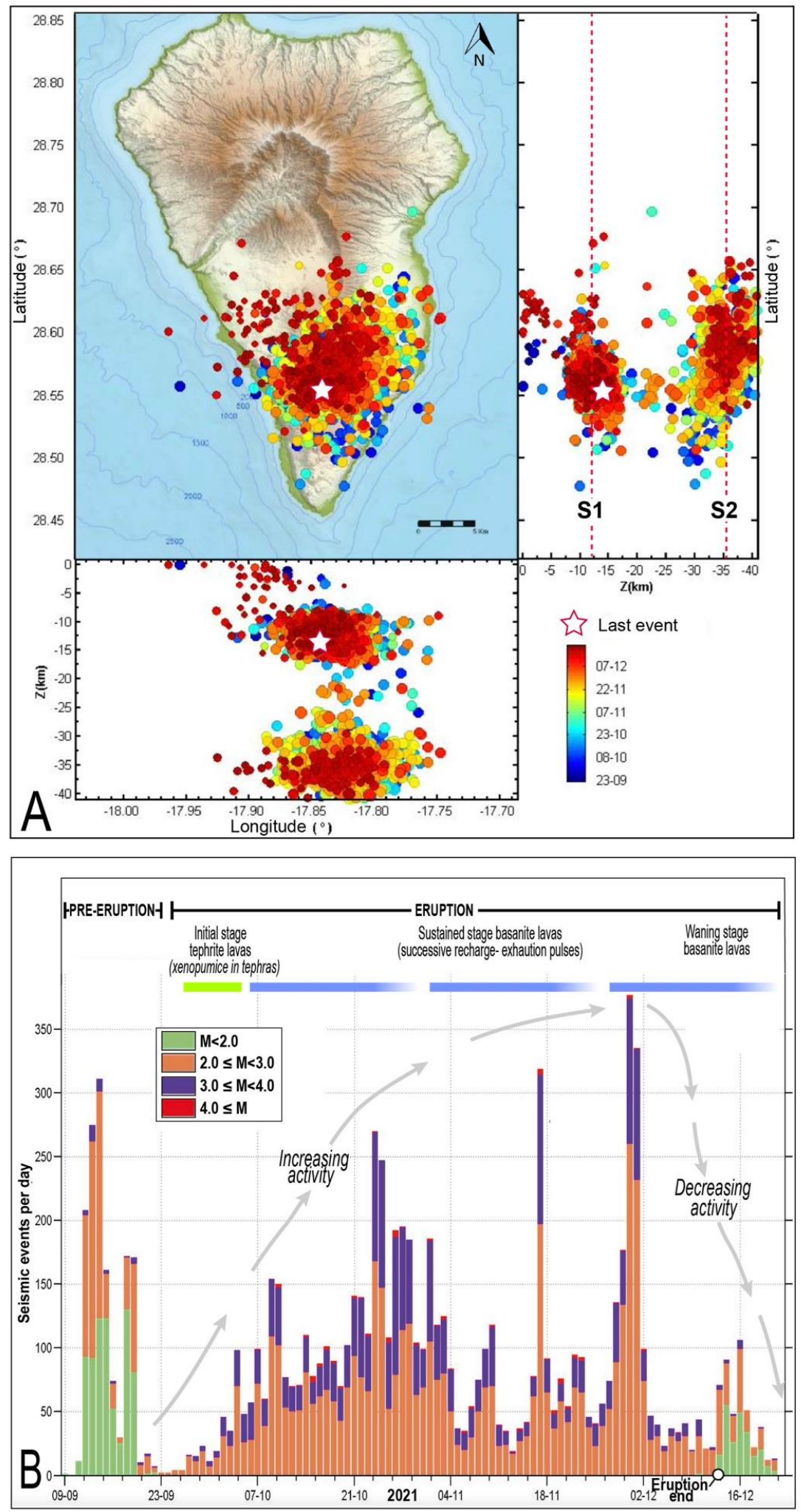

Fig. 8 . 


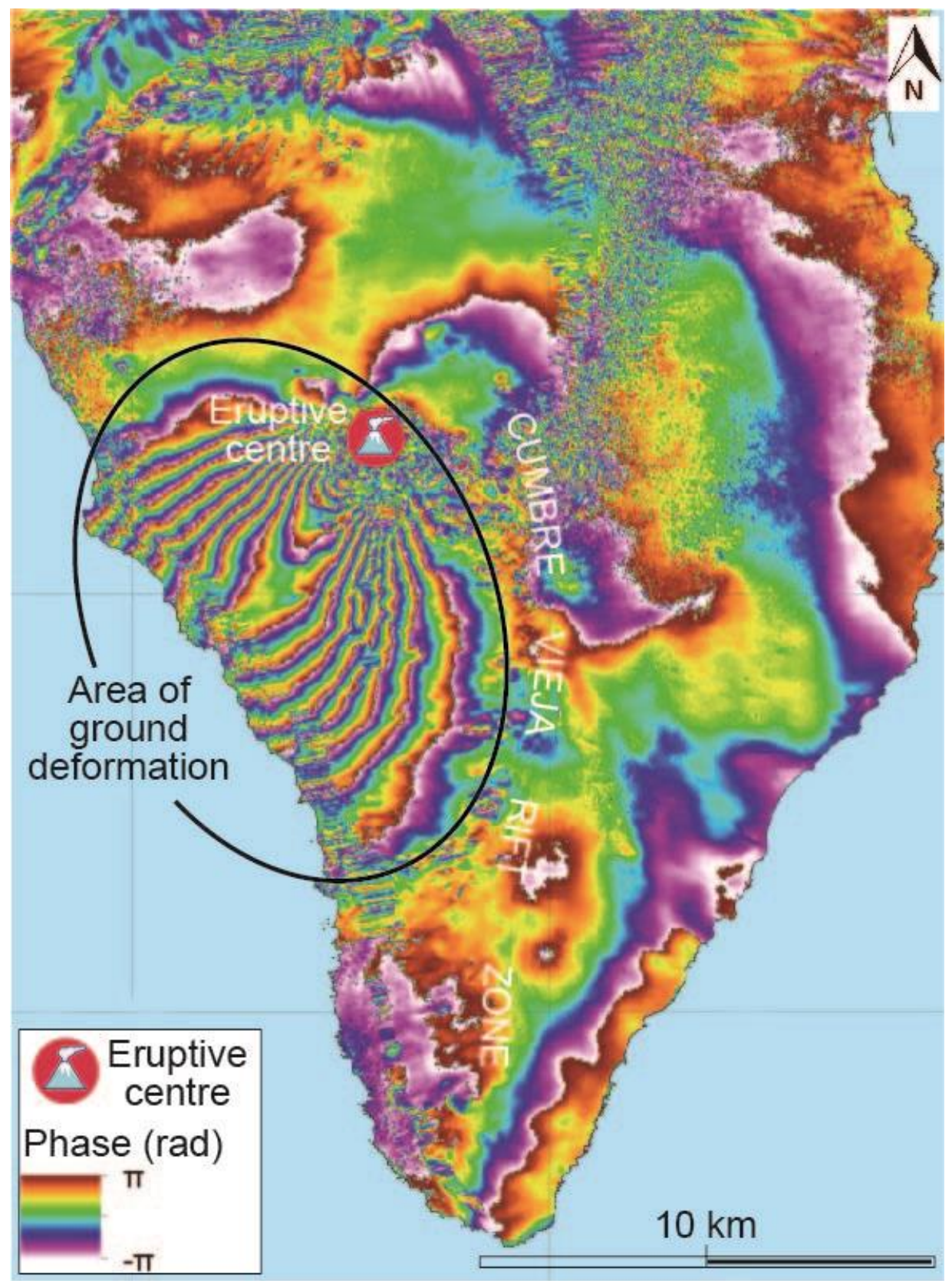

Fig. 9 


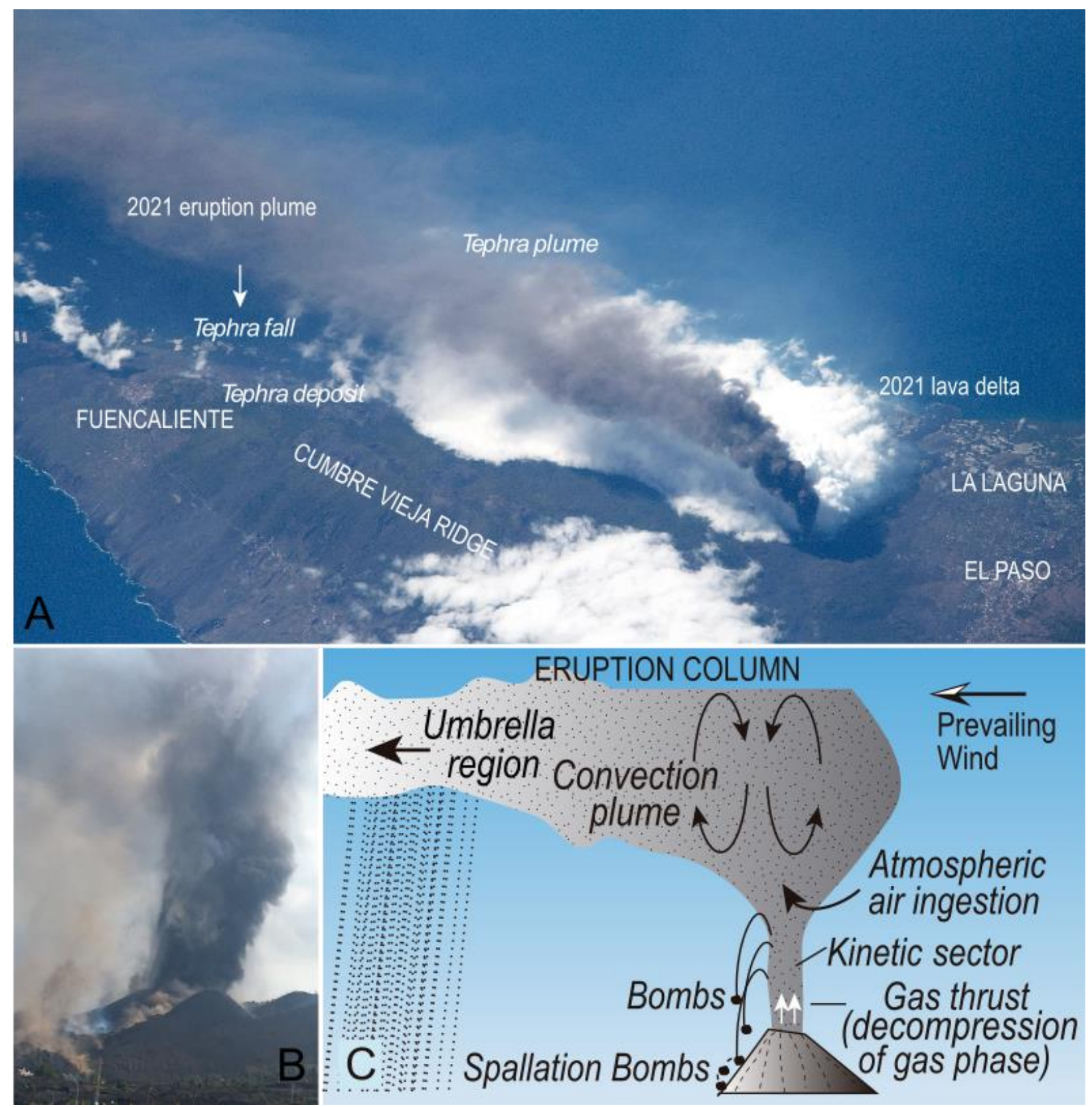

Fig. 10 


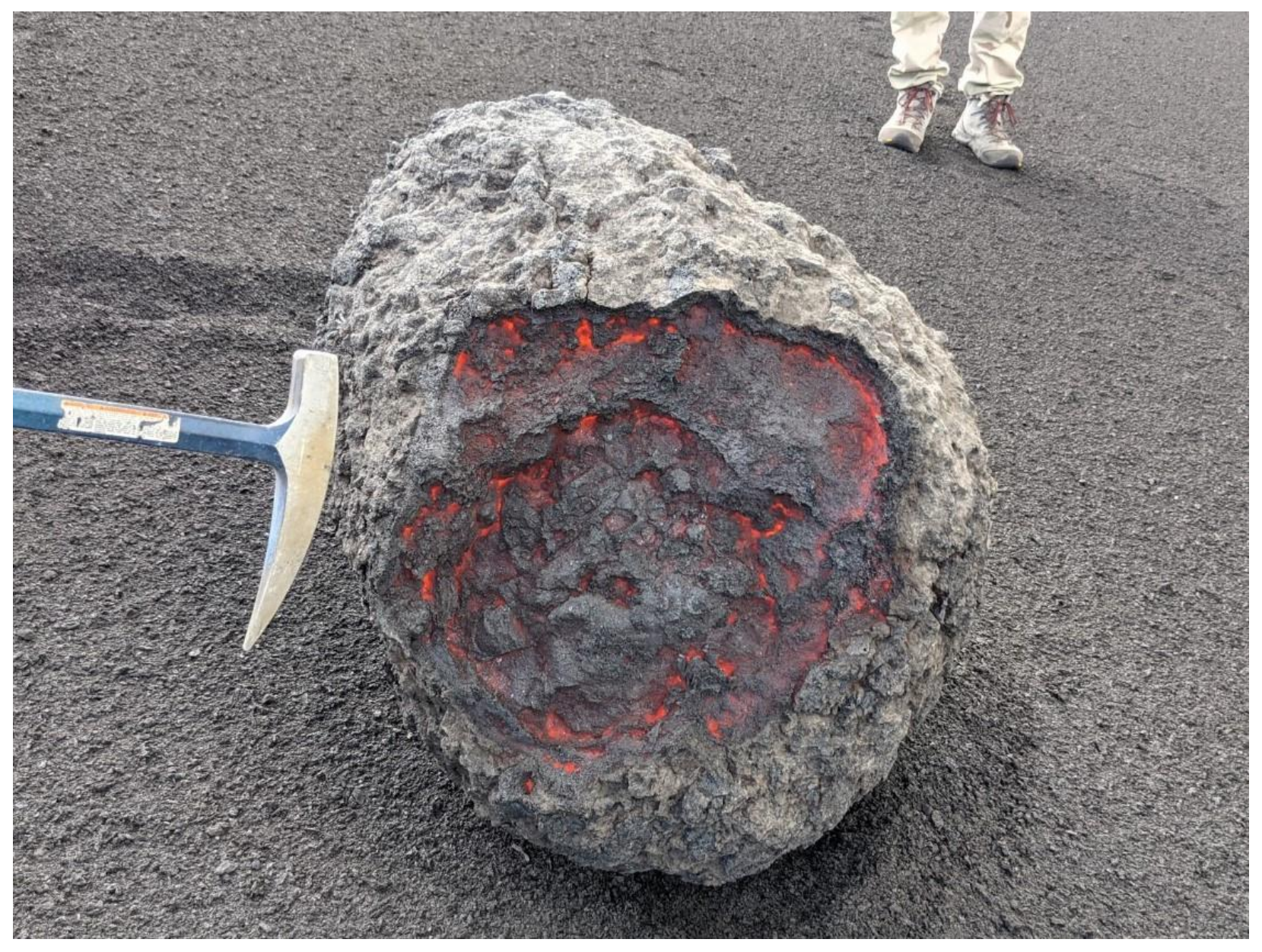

Fig 11. 

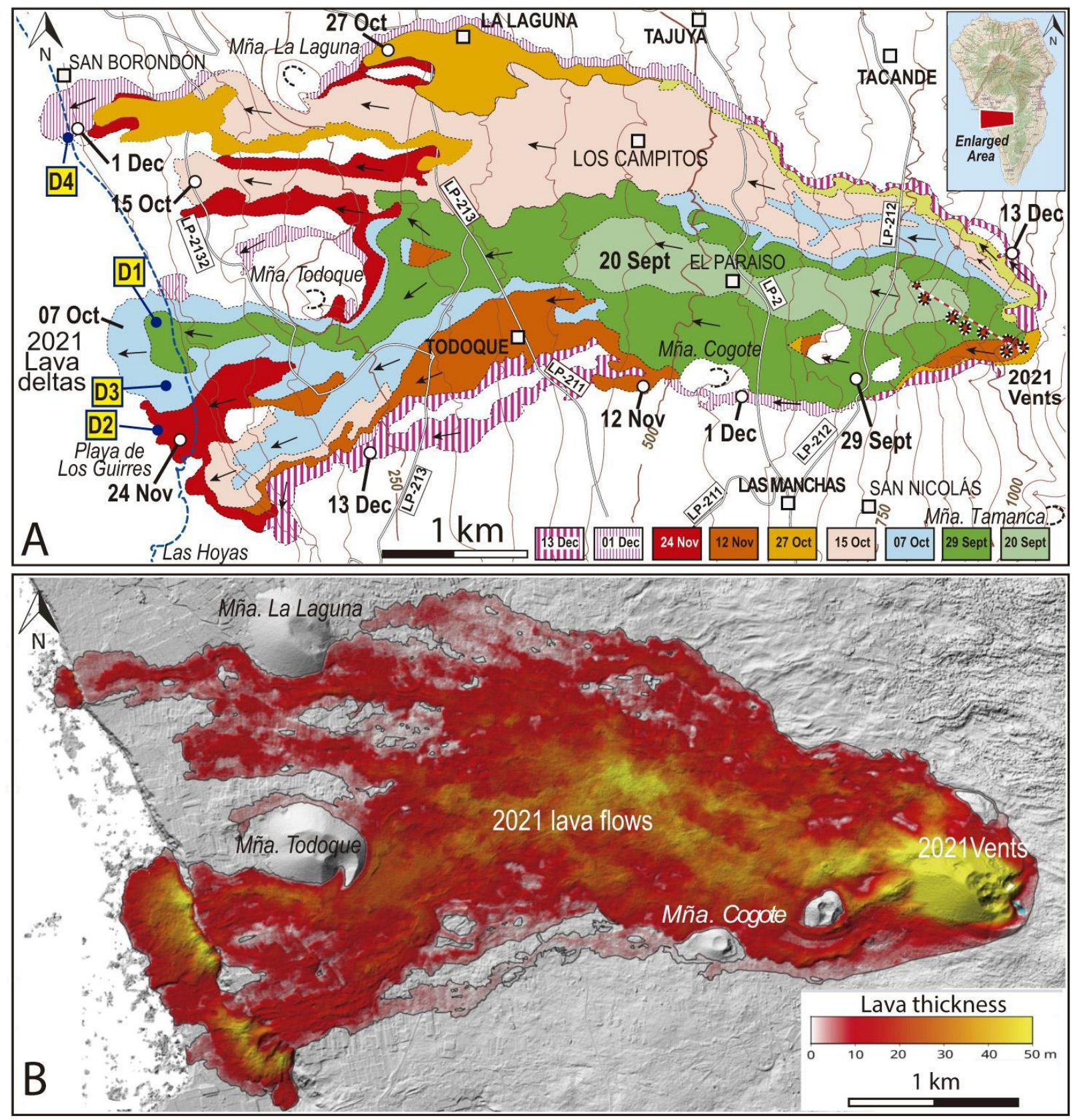

Fig. 12 

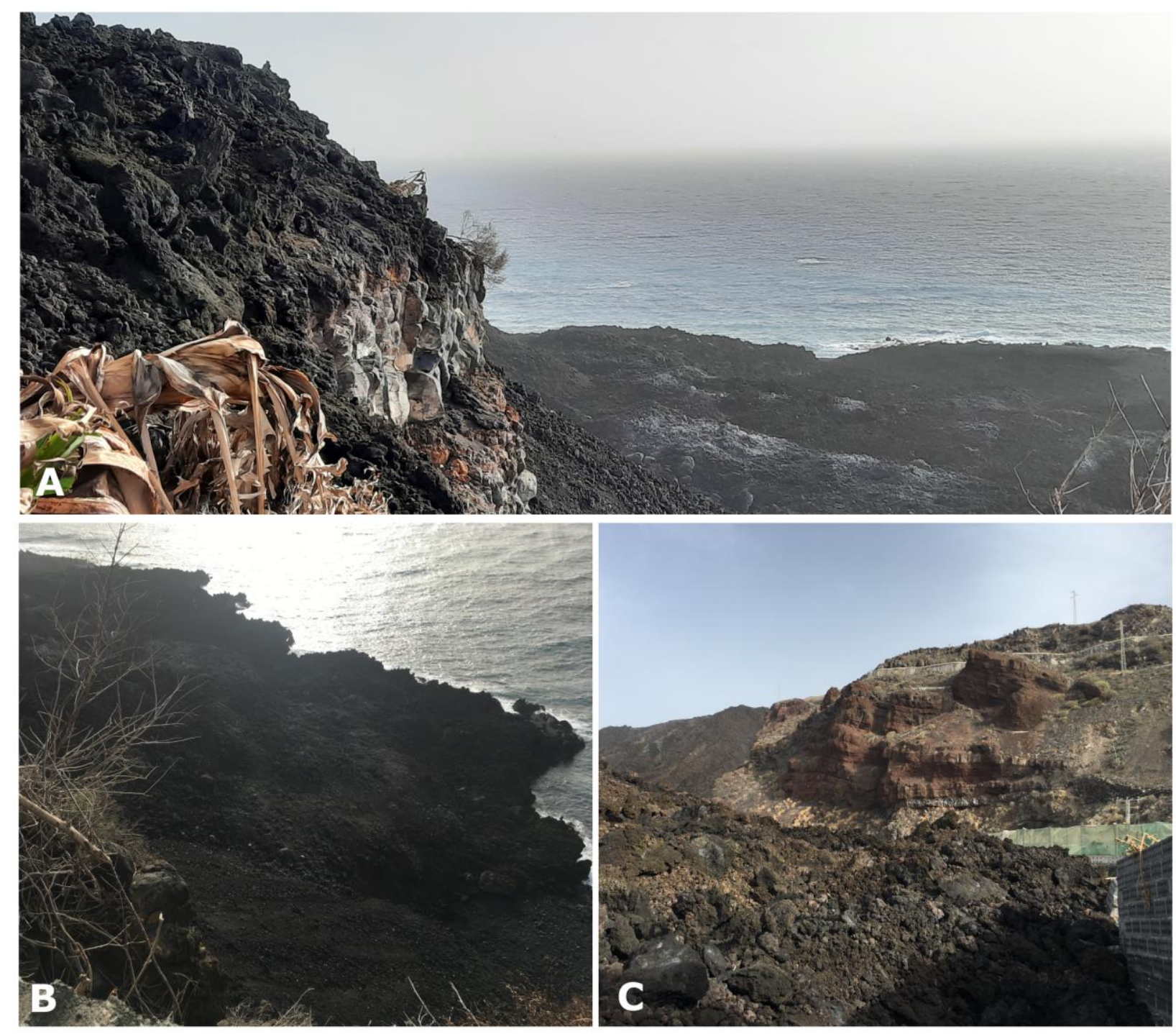

Fig. 13 

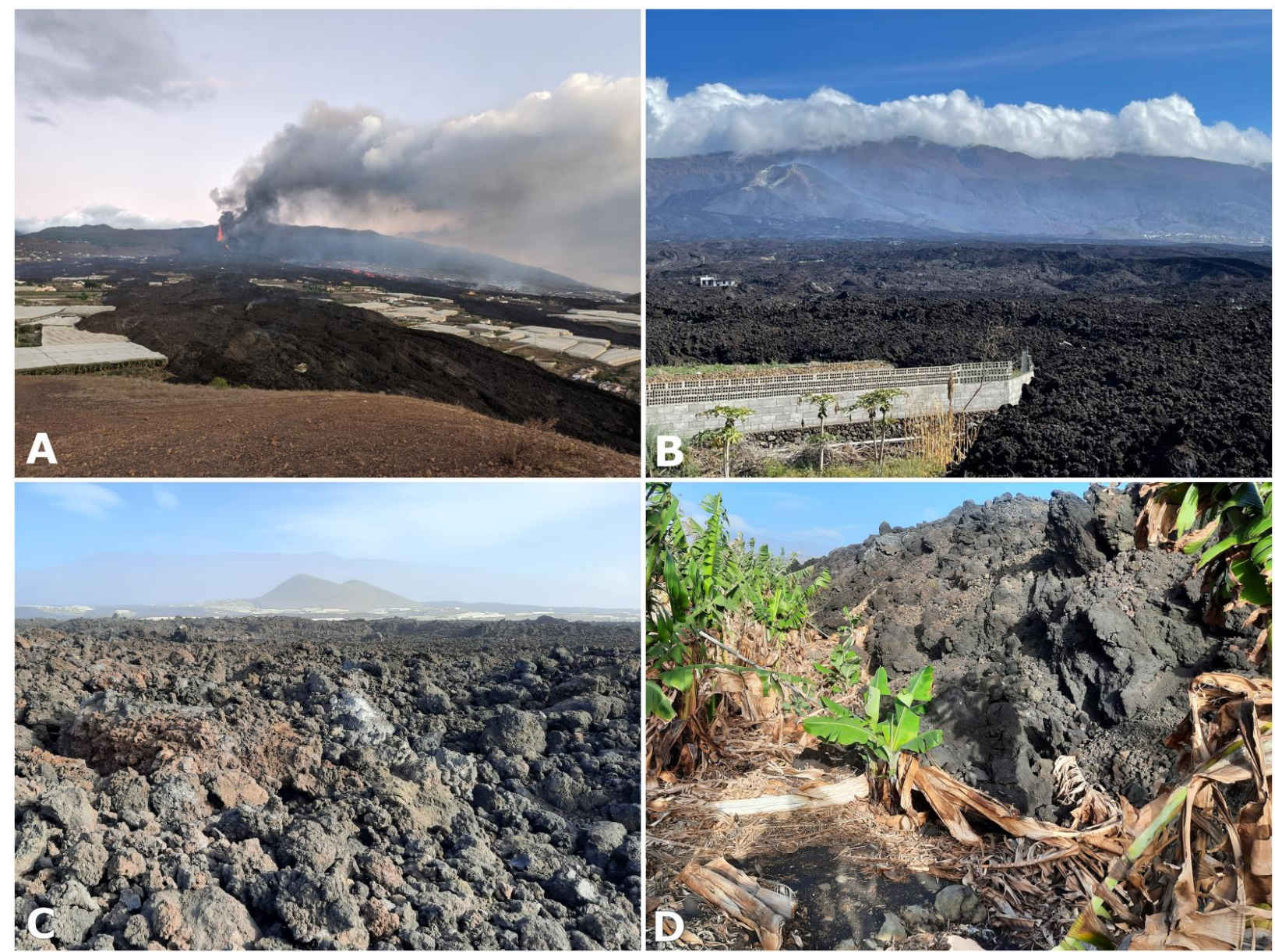

Fig 14 


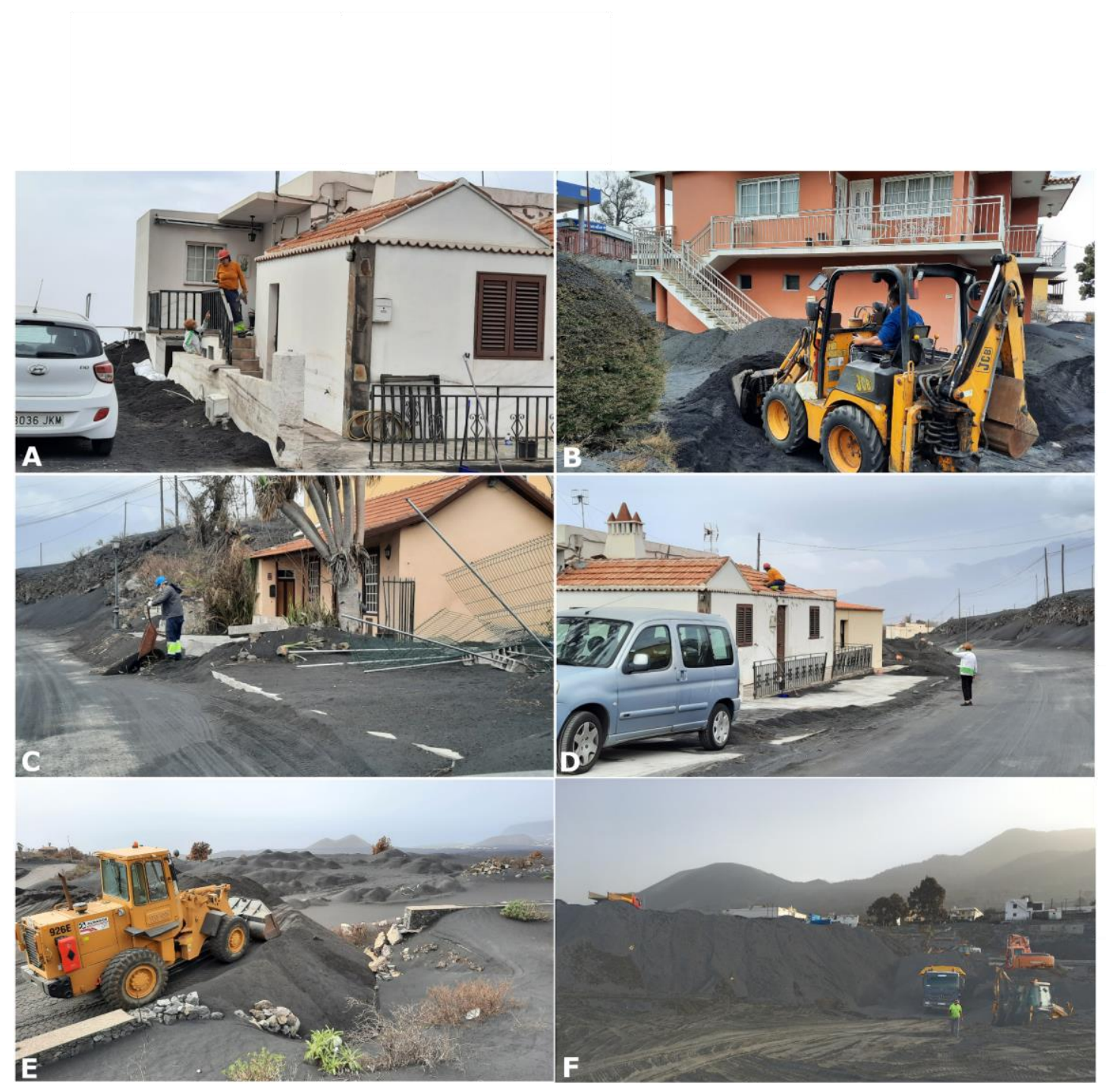

Fig. 15 


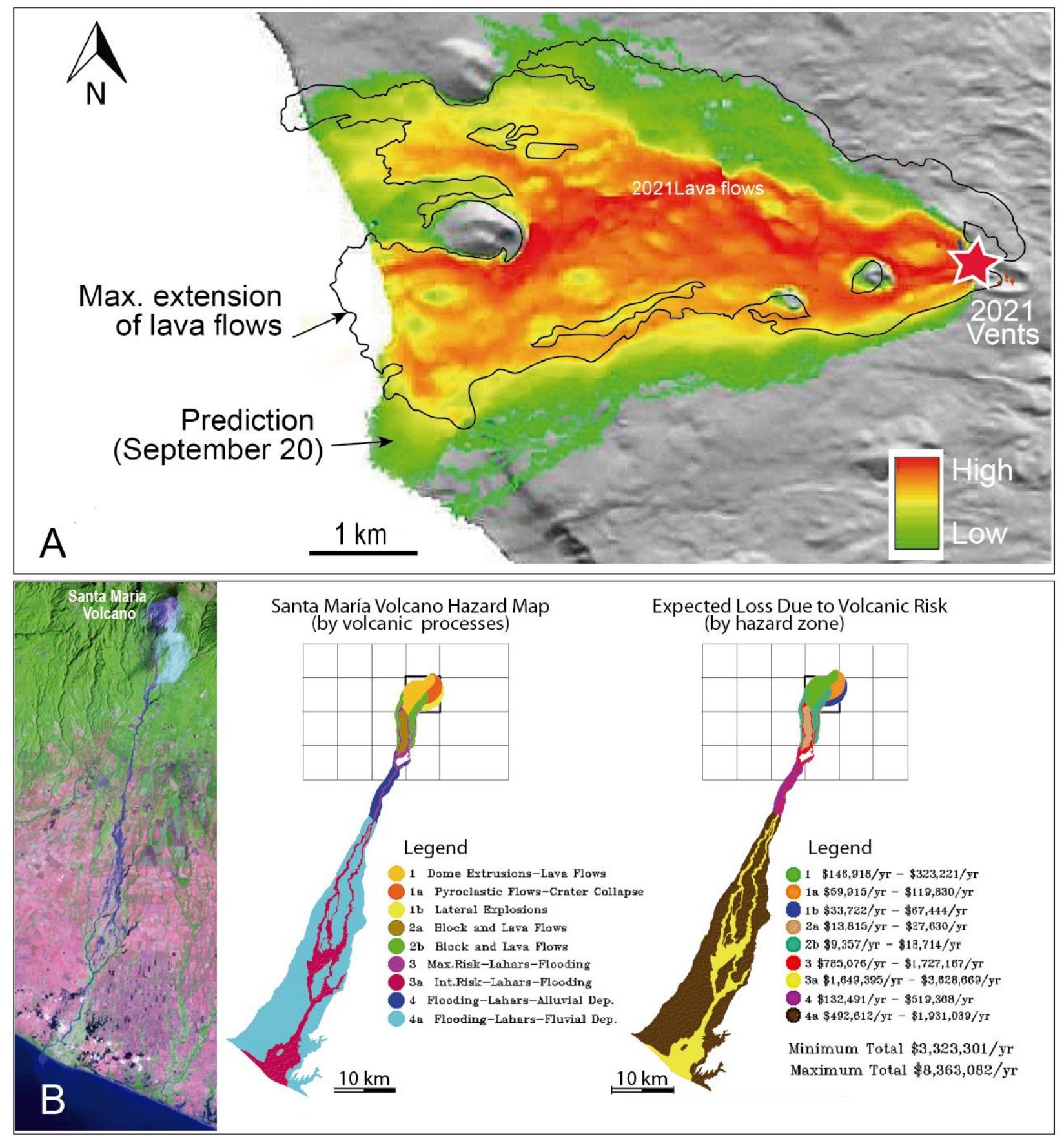

Fig. 16 
Table 1. Some critical features of the Canary Islands historical eruptions (last 500 years). Seven eruptive events out of 15 have occurred in La Palma, including this 2021 latest eruption

\begin{tabular}{|c|c|c|c|c|c|}
\hline Year & Island & Eruption & $\begin{array}{l}\text { Seismic } \\
\text { precursors }\end{array}$ & $\begin{array}{l}\text { Duration } \\
\text { onset-end }\end{array}$ & Days \\
\hline 1492 & Tenerife & Boca Cangrejo $^{1}$ & & & \\
\hline 1585 & La Palma & Jedey/Tajuya & $\sim 50$ days & May 19-Aug 10 & 84 \\
\hline 1646 & La Palma & Martin/Tigalate & 1 day & Oct 01-Dec 21 & 82 \\
\hline $1677-78$ & La Palma & Fuencaliente & $\sim 4$ days & Nov 17-Jan 21 & 66 \\
\hline $1704-05$ & Tenerife & $\begin{array}{l}\text { Siete Fuentes } \\
\text { Fasnia } \\
\text { Arafo }\end{array}$ & $\sim 1$ month & $\begin{array}{l}\text { Dec 31-Jan } 05 \\
\text { Jan 05-15 } \\
\text { Feb 02-Mar } 27\end{array}$ & $\begin{array}{l}66 \\
10 \\
53\end{array}$ \\
\hline 1706 & Tenerife & Garachico & 1 year & May 5-Jun 13 & 39 \\
\hline 1712 & La Palma & El Charco & $\sim 5$ days & Oct 09-Dec 03 & 56 \\
\hline $1730-36$ & Lanzarote & Timanfaya & $\sim 6$ years & $\begin{array}{l}\text { Sep } 01,1730- \\
\text { Apr 2, } 1736\end{array}$ & 2041 \\
\hline 1798 & Tenerife & Chahorra & $\sim 3$ years & Jun 09-Sep 15 & 99 \\
\hline 1824 & Lanzarote & $\begin{array}{l}\text { Tao } \\
\text { Nuevo } \\
\text { Tinguatón }\end{array}$ & $\sim 11$ years & $\begin{array}{l}\text { Jul 31-Aug } 01 \\
\text { Sep 29- Oct } 05 \\
\text { Oct } 16-24\end{array}$ & $\begin{array}{l}2 \\
7 \\
9\end{array}$ \\
\hline 1909 & Tenerife & Chinyero & $\sim 2$ years & Nov 18-27 & 9 \\
\hline 1949 & La Palma & San Juan & $>2$ years & Jun 24-Jul 30 & 37 \\
\hline 1971 & La Palma & Teneguía & $>1$ month & Oct 26-Nov 18 & 24 \\
\hline 2011-12 & El Hierro & Tagoro $^{2}$ & $>4$ years & Oct 10 -Feb 15 & 129 \\
\hline 2021 & La Palma & Cabeza de Vaca & $\sim 4$ years & Sep 19-Dec 13 & 85 \\
\hline
\end{tabular}

1 The eruption reported by Christopher Columbus 2 Submarine eruption 